\title{
Understanding the Role of Team Member Personal Style in Project Performance: Does the Type of Innovation Matter?
}

\author{
Zvi H. Aronson*, Richard R. Reilly ${ }^{\dagger}$ and Gary S. Lynn* \\ School of Business, Stevens Institute of Technology \\ Hoboken, USA \\ *zvi.aronson@stevens.edu \\ †rreilly@stevens.edu \\ †lynn@stevens.edu
}

Received 29 September 2017

Accepted 23 April 2018

Published 29 August 2018

\begin{abstract}
Teams are progressively becoming primary in the way employees in organizations conduct work. We investigated the role of staff personal style in project performance for teams working on incremental and radical innovations. Regression results based on 149 teams suggest that, for employees, conscientiousness and agreeableness, predominantly, seem to be beneficial for new product development (NPD) performance. Slope tests promote our proposition that for speed, radical NPD might gain from extra open and stable staff. Further, exceedingly agreeable employees do not seem to provide support when new ideas are fostered, since it could be a precursor to group think and less successful innovation. We provide implications for selection and training of employees assigned to work in innovation teams.
\end{abstract}

Keywords: Project teams; innovation; personal style.

\section{Introduction}

When new product development (NPD) speed and success are critical, what can organizations establish? Of the many variables examined that affect how fast an idea moves from conception to a successful product in the marketplace, staff member characteristics play an important role [e.g. Chen et al. (2010)]. Staff members are the people who transform value ideas, concepts specifications into new products, and they are a key in facilitating NPD speed and success [Brown and Eisenhardt (1995)] we refer to as NPD performance. Scholars document the value of team member dedication and cooperation to increased NPD performance [e.g. Atuahene-Gima (2003); Hoegl et al. (2004); Keller (2001)]. Researchers [e.g. Aronson et al. (2006, 2008); Strang (2011)] center on the role of leader personal style in NPD performance. Yet, few scholars examine the role of staff member personal style in NPD performance, for teams working on different types of innovations. Personal style traits have considerable utility for predicting how people behave and perform in the workplace [e.g. Barrick et al. (2001)]. Can optimum personal style selection criteria

*Corresponding author. 
be established for individuals assigned to work in innovation teams? How might the optimal team personal style profile change for NPD employees working on radical innovations?

Because teams developing innovations work in a context ripe with uncertainty, handling this uncertainty should place special demands on the staff of such teams. Researchers suggest that staff personal style effects ought to be examined in different kinds of teams, including cross-functional task teams in management and NPD teams [e.g. Reilly et al. (2002)]. To this end, we consider the role of staff member personal style in NPD performance for two different types of NPD teams: radical and incremental. (1) Radical NPD occurs when the market for the product is not clear and the technology used is new and uncertain; (2) Incremental NPD occurs when the markets are well-established and there are few questions about the technology.

In the following sections, we describe radical and incremental NPD teams, and the Five-Factor model (FFM) of personality we use as a framework for organizing the research on personal style traits. We then examine the role of staff member personal style in NPD performance. Unlike past research that mostly focuses on the leader's personal style, our research provides a theoretical rationale and hypotheses on the links between staff member personal style and NPD performance, and furthermore addresses the question of whether different staff member personal styles are needed depending on the type of innovation - radical or incremental, which has been called for [e.g. Barrick et al. (2001)].

\section{Theoretical Background}

Researchers have distinguished between two broad types of innovations that differ in the extent to which the innovation is similar to or different from existing practice. Radical innovation represents significant change for the firm, and often opens up new markets and potential applications. Radical innovations include products completely new to the firm, products based on new technologies and new ventures unrelated to existing businesses. Such major innovations require skills, abilities, and knowledge different from those required to master the old technologies. Incremental innovation, in contrast, introduces relatively minor changes to an existing product. Incremental innovations are related to the firm's current products and businesses, and generally take the form of product modifications, upgrades, and line extensions. These innovations build on existing know-how [e.g. Tushman and Anderson (1986)] Because the nature of these innovations differ, the literature argues that teams performing these innovations be different [Barczak and Wilemon (1991)]. For example, Barczak and Wilemon note that teams responsible for radical innovation should be autonomous and separate from the existing organization. The more dissimilar the technology or markets from current practice, the greater should be the use of independent venture forms, they argue. NPD teams are accordingly assembled to implement their tasks outside the established organization structure. Indeed, high levels of autonomy are reported throughout the teams studied in an investigation by Gemünden et al. [2005]. Gemünden and colleagues' work implies that high levels of autonomy also pose severe challenges (e.g. access to complementary resources 
is more difficult for separated units than for embedded units) for these NPD teams. In contrast, routine and related new products are best suited to be carried out within the firm's existing divisions and units. These differences have implications for the way these teams are effectively staffed, and for the personal style traits their employees should possess. However, research on the optimal personal style traits the staff members should have in these respective teams is scarce. The research we identified focuses on the project leaders' personal style. To this end, we also examine the role of staff member personal style traits in NPD performance for teams developing radical and incremental innovations. We next describe the FFM of personality we use as a framework for organizing the research on personal style traits.

\subsection{Personal style as captured by the FFM}

In this research, we focus on the effect of personal style variables as captured by the FFM. The FFM represents the current orthodoxy in personal style assessment and is a simple, robust, and comprehensive way of understanding fundamental personal style differences [Barrick and Mount (1991); McCrae and Costa (1996)]. Although it has its critics, general consensus suggests that it adequately captures the content domain of personality [Wiggins (1996)].

Meta-analytic research [e.g. Barrick and Mount (1991); Hurtz and Donovan (2000); Tett et al. (1991); Salgado (1997)] suggests that personal style traits, as measured by the FFM, have considerable utility for predicting how people behave and perform in the workplace. Of particular interest is evidence [Tett et al. (1994); Day and Silverman (1989); Barrick and Mount (1991)] that specific personal style traits are related in predictable ways to performance in certain kinds of jobs. A metaanalysis by Judge et al. [2002] provides support for the relevance of the FFM as a framework for organizing personal style traits in research. The dimensions comprising the FFM are emotional stability, openness, conscientiousness, agreeableness, and extraversion (often termed the Big Five). Emotional Stability represents the extent to which an individual is calm, enthusiastic, poised, and secure. Openness represents the extent to which an individual is imaginative, sensitive, intellectual and polished. Conscientiousness represents the extent to which an individual is careful, thorough, achievement-oriented, responsible, organized, self-disciplined, and scrupulous. Agreeableness represents the extent to which an individual is good-natured, gentle, cooperative, forgiving, and hopeful. Extraversion represents the extent to which an individual is sociable, talkative, assertive, and active [e.g. Aronson et al. $(2006,2008)$; Barrick et al. (2001)].

Our central hypothesis, rooted in earlier work and detailed later, is that the effect of two personal style traits, conscientiousness and agreeableness will be most important in their influence on the performance of NPD teams [e.g. Barrick et al. (1998); Hough (1992); Kichuk and Wiesner (1997); Neuman and Wright (1999)]. Conscientiousness is related to performance outcomes across jobs [e.g. Barrick and Mount (1991); Barrick et al. (2001); Salgado (1997)]. Agreeableness is vital in teambased contexts [Aronoff and Wilson (1985); Costa and McCrae (1989)]. To test these initial hypotheses, we will scrutinize the beta weights when all staff personal style 
variables are entered into a multiple regression equation. Additionally, based on previous research [e.g. Driskell et al. (1988); Bouchard (1972); DeBiasio (1986); Tuckman (1967)], we posit that when considering the type of innovation the teams are working on, the relationship between staff personal style traits and NPD performance criteria will vary, as we elaborate below. To examine these final propositions, we will compare the slopes and intercepts of the regression lines for each of the staff personal style variables, detailed in the method section.

It is noteworthy that although a couple of our research propositions are stated for two categories of teams, incremental and radical, which we define below, it is important to recognize that the variables that distinguish between the two teams are continuous. Thus, a proposition that suggests a zero correlation between a personal style variable and NPD performance does not necessarily imply that the variable is completely unimportant, but rather that it is unlikely to distinguish successful from unsuccessful teams. As an example, a threshold level of creativity may be important for incremental NPD teams but may not differentiate success from failure. On the other hand, the level of creativity beyond the threshold level might have a significant relationship with performance outcomes in radical NPD teams.

\subsection{Radical versus incremental NPD teams}

Two major types of teams responsible for NPD have been identified: operating and innovating [Barczak and Wilemon (1989)]. Operating teams are concerned with maintaining competitive positions in existing businesses and, as a result, they usually focus on incremental innovation or small improvements to current products. Characteristics of these groups include operating in relatively stable environments, being rule and planning-oriented, and emphasizing current products. Innovating teams, in contrast, focus on developing a new business for the firm. They are more likely to focus on important new products for unfamiliar markets. These types of teams produce radical or discontinuous innovations. The development of radical innovations is associated with more challenges than the development of incremental ones [O'Connor and Veryzer (2001)]. Teams developing radical innovations are usually separated from the daily activities of the firm. Characteristics of innovating groups include operating in a dynamic environment, emphasizing initiative and risk taking and maintaining loose methods of control. These product development teams must choose an innovation strategy that is tailored to the degree of market and technology uncertainty [Ansoff (1965, 1988); Moriarty and Kosnik (1990)]. These two major types of NPD teams have been labeled Incremental and Radical [Lynn and Akgun (1998)]. In the current study, we focus on the effect of staff personal style on performance, in incremental and radical NPD teams.

Incremental innovation exists under highly certain environments, when a currently served market with mature technologies is targeted. Incremental innovations may include product changes or improvements, product line extensions, and "me too" products that are similar to the competition. A good example of incremental innovation is the double stuff Oreo cookie by Nabisco. Under such conditions, the appropriate innovation strategy focuses on being market-based and process-based. 
The customers are well defined and are typically well known, as is the technology required to produce the innovation. This type of innovation usually encounters fewer surprises than the more radical type.

Radical innovation, in contrast, exists when both market and technology uncertainties are high. Innovations of this type pose severe challenges for new product teams because the market is not well understood, and the product is still evolving and changing with the market. These types of innovations require focus on a learning-based strategy because experimenting is an essential component of the process. Product teams may try a product in the market to learn, improve it, and try it again [Lynn et al. (1996)]. For example, the early video cassette recorder (VCR) models were too expensive and limited and consequently, they failed in the marketplace. However, manufacturers continued to interact with users, learned from them, and accordingly improved the technical performance of the VCR, reduced its price, and successfully reintroduced the product to the market [Rosenbloom and Cusumano (1987)]. Scholars suggest that different personal styles are required depending upon the team's task. Because NPD teams differ with respect to typical tasks, scholars [e.g. Driskell et al. (1987); Bouchard (1972); DeBiasio (1986); Tuckman (1967)] would suggest that it is important to consider the role of staff personal style for different types of NPD teams.

\subsection{Personal style and product development teams}

Research on team member personal style has provided some interesting insights, but has left some unanswered questions in terms of the relationship with team outcomes, and the importance of personal style variables for diverse teams [Altman and Haythorn (1967); Burchfield (1997); Driskell and Salas (1992); Hogan and Hogan (1989); Oser et al. (1989); Morgan and Lassiter (1992); Schutz (1955)]. While these studies show significant relationships for some variables, the results are difficult to interpret and apply to NPD teams for two reasons. The first reason has to do with the inconsistency of the personal style framework used in the different research. Not all studies use the Five Factor Personal Style Framework. With some exceptions, the research is often marked by inconsistent constructs used to define personal style. A second problem with the past research is that many of the studies have been done with simulated teams and short-range tasks or projects, sometimes consisting of tasks less than an hour's length. As an example, a number of studies have investigated the relationship between team-member personal style and creativity as the team outcome [e.g. Bouchard (1969); DeBiasio (1986); George and Bettenhausen (1990); Strube et al. (1989)]. All of these studies were done in laboratory settings.

We identified a few studies that directly examined the role of personal style in NPD project outcomes, none of which included speed among the performance criteria, nor did these studies differentiate between various kinds of innovation teams. Most of the research we uncovered focused on the project leaders' personal style [e.g. Aronson et al. (2006, 2008); Strang (2011)]. One study examined relationships between the personality of an "Analyst", who evaluates product ideas at the fuzzy front end. The period between when the opportunity for NPD and when a serious effort 
is mounted on the development project is known [Smith and Reinertsen (1997)]. Another study [Stevens et al. (1999)] found significant differences between the number of decisions and the degree of success for different personality styles. Although this research does not directly bear on the issue of team performance outcomes, it provides evidence for the impact of personal style on NPD. Research [Kichuk and Wiesner (1997)] done with simulated NPD teams, found significant differences between successful and unsuccessful teams for average team member scores on extraversion, agreeableness, and neuroticism (instability).

Because we are dealing with teams, the role of personal style within a team can take two different forms. First, the average level of a particular personal style variable within the team may be related to team performance. Second, the degree of heterogeneity of a particular trait may play a role in team performance. The average level of a personal style trait is usually indicated by the mean of a variable. For a single variable, the variance or standard deviation would be an indicator of the degree of heterogeneity of the team. For multiple variables, a variety of distance measures such as Euclidian, Squared Euclidian or City Block metrics could be used to characterize the heterogeneity of a team. Our hypotheses are related to the average level of a particular personal style variable within an NPD team and NPD performance criteria, including speed and success. The speed criterion included the extent the NPD project was developed and launched faster than the major competitor for a similar product, was completed in less time than what was considered normal and customary for our industry, was launched on or ahead of the original schedule developed at initial project go-ahead and the extent top management was pleased with the time it took us from specs to full commercialization. The success criterion included the extent the project overall met or exceeded sales expectations, met or exceeded profit expectations, met or exceeded return on investment expectations, met or exceeded overall senior management's expectations, met or exceeded market share expectations, met or exceeded customer expectations. These performance criteria are frequently mentioned in the literature [e.g. Lynn et al. (2000)], are detailed in the methods section, and are important in the context of our investigation of NPD staff personal style and performance in project-based work for several reasons, described in the following sections.

\subsubsection{Conscientiousness}

We posit that the average level of NPD staff on conscientiousness should be important for NPD performance in several ways. In particular, conscientious staff tend to be reliable [Costa and McCrae (1992)], which should be important for NPD speed, where sticking to a certain schedule is important. Conscientious employees are inclined to be achievement-oriented, which ought to be essential for NPD, where setting high goals and working harder to achieve these goals may result in the development of a product faster than competitors for a similar product, thus meeting overall senior management expectations. Researchers [e.g. Keller (1997)] support the contention that conscientiousness should be predictive of NPD performance in general for scientists and engineers. 
Scholars illustrate the value of team member conscientiousness for team performance outcomes across settings [e.g. Barrick et al. (1998); Guzzo et al. (1992); Neuman and Wright (1999); Schneider and Delaney (1972); Zander and Forward (1968)]. Studies on person-role congruence show that team effects occur as a result of the match between personal style characteristics and staff members' roles [Shaw and Harkey (1976)]. Because conscientiousness predicts performance outcomes across job categories and criteria [e.g. Barrick and Mount (1993)], investigators suggest that conscientious staff should be dedicated to implementing the multiple role requirements of teams. Accordingly, it is conceivable that conscientious NPD staff members will concentrate on fulfilling the needs of the team, possibly affecting the success of the NPD project, and the pace in which the NPD project is implemented.

Conscientious NPD members tend to be task-focused and self-disciplined as well, which ought to result in team member attention to goal accomplishment [LePine et al. (1997)]. The tendency to be task focused can reduce the likelihood of social loafing [e.g. Karau and Williams (1993)], which in turn could affect the extent the NPD project is developed and launched faster than the major competitor for a similar product and perhaps the extent market share expectations are met.

Researchers [e.g. Brown and Eisenhardt (1995); Gemünden et al. (2005); Imai et al. (1985)] report that for fast product development, staff members had relative freedom to work autonomously, making the conscientiousness of NPD staff members a valuable trait, when it comes to launching the project on or ahead of the initial schedule and perhaps meeting management expectations. Accordingly we propose that the level of NPD staff conscientiousness should be related (highest beta weights when all personal style variables are entered into a multiple regression equation) to NPD performance.

H1: Staff member conscientiousness will be positively related to NPD performance.

\subsubsection{Agreeableness}

The literature [e.g. Imai et al. (1985); Keller (1986)] illustrates the value of continuous communication among NPD project staff members. Constant communication increases the information flow among team members, making it easier for team members to understand each other's specialties and to coordinate. Because agreeable team members tend to be trusting and straightforward [Costa and McCrae (1989)], they should facilitate communication with others on the team, in pursuit of NPD team's objectives [Aronoff and Wilson (1985)].

Further, agreeable people tend to be sympathetic to others and willing to help, and believe that others will be equally helpful in return. Helpful staff members might inform each other about non-routine demands, allowing them to take steps to mitigate problems, contributing to completion of the NPD project on schedule. NPD project participants who voluntarily disseminate their functional expertise to fellow staff members further expose their associates to diverse information [Katz and Tushman (1981)]. Such increased information sharing should further help NPD staff members to catch downstream problems such as manufacturing difficulties or 
marketing mismatches, before they happen, when these problems are generally smaller and easier to fix [Brown and Eisenhardt (1995)], and perhaps also consume less project time. It is plausible that NPD staff who help each other out would not have to turn to their project managers for assistance, leaving the project managers free to carry out more important tasks, such as obtaining needed personnel and securing financial support, resulting in the NPD project achieving its goals, and meeting senior manager and customer expectations. Further, in the demanding project setting, in which resources and goals are uncertain and customer demands are evolving, the less time project participants consume complaining or finding fault with project colleagues, the more time these agreeable individuals can invest in more productive purposes, perhaps affecting the time it takes from specs to full commercialization (highest beta weights when all personal style variables are entered into a multiple regression equation). Based on the literature reviewed, we arrive at our second hypothesis.

H2: Staff member agreeableness will be positively related to NPD project performance.

\subsubsection{Extraversion}

In a team setting, scholars report that higher scores on extroversion should relate to higher levels of social activity [e.g. Barczak and Wilemon (1991)]. Interestingly, the research on the value of extraversion for team performance outcomes is mixed. Some scholars show that extraversion is related to group creative problem solving [e.g. Bouchard (1969)], effectiveness [e.g. Greer (1955)] and team viability [e.g. Barrick et al. (1998)]. Other researchers [e.g. Kirkman and Rosen (1999)] provide empirical evidence that a proactive personality, which is consistently associated with two of the FFM factors, one of which is extraversion [e.g. Bateman and Crant (1993); Crant and Bateman (2000)], is positively related to work group performance outcomes. Yet, other investigators [e.g. Gurnee (1937)] report a positive relationship between group members' extraversion and the number of errors that groups make. Still other researchers [e.g. Barry and Stewart (1997)] find a negative relationship between extraversion and task focus. Finally, additional assessments [e.g. Kichuk and Wiesner (1997)] using simulated NPD teams, show higher levels of extraversion in teams that succeeded in meeting their objectives. In sum, due to the inconsistent results in the literature on the value of staff member extraversion in team contexts, we do not provide a hypothesis for this personal style.

In the next section, we consider personal style traits that might be important for NPD performance criteria, speed or success, depending upon the type of innovation, radical or incremental. Figure 1 will guide the literature review leading to the remaining hypotheses.

\subsubsection{Openness}

Scholars [e.g. Driskell et al. (1987); Bouchard (1972); DeBiasio (1986); Tuckman (1967)] suggest that staff member openness should be more essential depending upon 


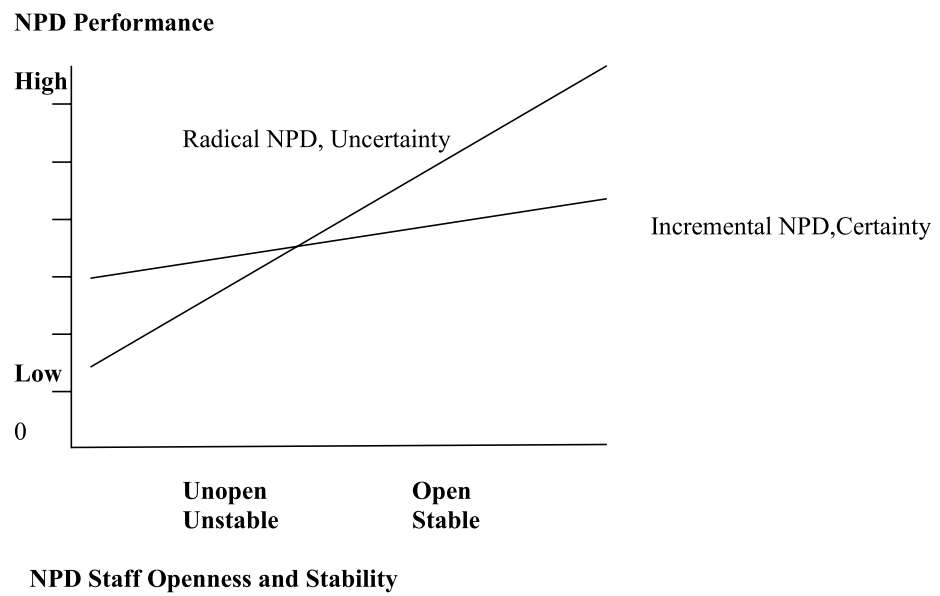

Fig. 1. Theoretical effect of the type of NPD team on the relationship between NPD staff personal style and performance. ${ }^{a}$

the type of NPD team. We argue that staff member openness should be valuable in NPD teams involved in creative tasks, or tasks performed under conditions of high uncertainty, characteristic of radical innovation, and less important for groups performing routine mechanical or structured tasks [e.g. Driskell et al. (1988)], characteristic more of incremental innovation. Investigators illustrate that openness is positively related to novel solutions $[\operatorname{McCrae}(1987,1996)]$, to "open communication" [e.g. Barry and Stewart (1997)], and is negatively correlated with conformity [e.g. Crutchfield (1955)].

Innovation is a process rife with uncertainty. Research shows that teams developing innovations deal with uncertainty internal to the firm and external to the firm. To handle this uncertainty, these teams must efficiently gather, process and disseminate information. In this vein, they can be viewed as information creating and processing systems. Open NPD staff can play a critical role in fostering this information. Open individuals are open to new ideas and information [Costa and McCrae (1992)], and open NPD staff should be open to new information whether it is from purchasing, vendor management, or the customer. Staff members who are open to new information, e.g. from the customer, could conceivably develop products that are perceived as new or different from existing products, or develop a completely new product that is acceptable in the market, at the pace of, or ahead of major competitors. These NPD teams need to obtain resources such as required talent, and larger budgets for the team [Brown and Eisenhardt (1995)], and open staff members could be more creative and resourceful when it comes to suggesting novel strategies for obtaining these resources, perhaps helping to reduce the time it takes to deliver the product to market.

Development teams, working on radical innovations, face severe challenges because the market is not well understood and the product is still evolving and changing with the market. These innovations require focus on a learning-based strategy because experimenting is an essential component of the process. Product

\footnotetext{
${ }^{\mathrm{a}}$ An example for NPD Staff Openness and Stability.
} 
teams may try a product in the market to learn, improve it, and try it again [Lynn et al. (1996); Rosenbloom and Cusumano (1987)]. NPD staff high in openness should be more successful on such trial and error research tasks that require maintaining flexibility and learning through experience, conceivably resulting in launching the NPD project at or ahead of schedule. Taken together, we propose that NPD staff openness will have a stronger positive effect on the NPD performance criterion speed, when the degree of uncertainty is high (The slopes and intercepts of the regression lines will be compared for each of the staff personal style variables), characteristic of radical innovation.

H3: Staff member openness will be positively related to NPD speed when innovation is radical, but will not be related to NPD speed when innovation is incremental.

\subsubsection{Emotional stability}

Teams with a higher aggregate level of emotional stability should contribute to a relaxed atmosphere and promote team cooperation. On the other hand, "unstable teams" are more likely to engage in disruptive behaviors, lose focus and have difficulty in cooperating [e.g. Watson and Tellegen (1985)], which could consume project time, plausibly affecting profit expectations. For teams that work on tasks over a long period of time, emotional stability can contribute to team viability [e.g. Haythorn (1953); Hough (1992)]. Unstable team members could be disruptive in meetings and have higher absenteeism, for example, both of which would slow progress. Additionally, emotional stability is paramount in team contexts, in terms of perceived self-efficacy for performing in self-managed teams and in terms of orientation toward job completion [e.g. Thoms et al. (1996)] as opposed to "nervousness tendencies" (i.e. instability).

Radical product innovation typically takes longer than incremental innovation, so teams must typically function together for longer periods of time - a condition that can make the favorability of the radical NPD staffs' moods and the emotional stability of the staff an important trait. The emotional stability of NPD staff members may be particularly important during radical NPD. Radical NPD encounters many more surprises than the incremental type, and the radical NPD staff members deal with conditions of high market and technology uncertainty. Having radical NPD staff members who are stable, and who do not waste time becoming frustrated when faced with the uncertainty, rapid change, and surprises involved with radical innovation could be particularly functional. Having team members with greater emotional stability might help buffer the radical NPD team from the stress associated with this uncertainty, thus enabling the team to continue functioning together over long periods of time, which can contribute to the completion of the radical NPD project on or ahead of its initial schedule. Emotional stability may be relatively unimportant for incremental NPD staff, who work under conditions that are more certain and routine.

H4: Staff member emotional stability will be positively related to NPD speed when innovation is radical, but will not be related to NPD speed when innovation is incremental. 


\subsubsection{Agreeableness}

Researchers suggest that having a team high on agreeableness could be associated with team cohesiveness, which under some conditions might lead to successful performance [e.g. McCrae and Costa (1989)]. Yet, when teams are highly cohesive they could also be susceptible to "groupthink" [Janis (1972)]. Teams with more agreeable members tend to be less conflictual [McCrae and Costa (1989)]. Researchers suggest that conflict and deliberation which is task related (cognitive) can have more benefits, depending on the nature of the goals and degree of uncertainty facing the team [Amason (1996); Jehn (1995)]. When innovation is incremental, teams are given clear, detailed goals, less deliberation is necessary and team members are able to organize the issues and accomplish their tasks efficiently [Cohen and Bailey (1997)]. NPD staff members who are less agreeable could bring about task related conflict and deliberation which is not beneficial given that project goals are clear. When innovation is radical, teams should benefit more from staff members that are less agreeable, in that, these individuals can foster the needed task related conflict. In fact, an argument could be made that agreeable staff, who are less conflictual, might inhibit the development of breakthrough ideas. Thus, we propose that staff agreeableness will have a stronger positive effect on NPD success when innovation is incremental.

H5: Staff member agreeableness will be positively related to NPD success when innovation is incremental, but will not be related to NPD success when innovation is radical

\section{Method}

\subsection{Sample}

We selected a contact person for 149 NPD teams in a variety of technology-based companies in the northeastern U.S. to participate in this study. To avoid industry bias, we sampled a variety of industries including telecommunications, computers and electronics, fabricated metal products, information services, pharmaceuticals, chemical manufacturing, food manufacturing, and machinery manufacturing. In each company, the contact person chose NPD professionals as respondents, detailed below. Respondents were asked by the contact person to select a completed NPD project and respond to the survey within one week. In order to achieve a large sample of projects, we gathered data on NPD projects during 2008-2009, following a pilot study that was conducted earlier. Our high response rate (94\%) was related to our use of participants in an executive management program, most of whom, worked in R\&D organizations.

The typical radical innovations in our study can be categorized as falling into one (some times more) of the following: electronics and computing, telecommunications, advanced materials and chemicals, pharmaceuticals. These categories are comparable to those presented by Veryzer [1998]. Specific examples of radical innovations in our research include Telcom Interactive Television, computer operating system, 
an automated mail processing system, MRS (Materials Research Society) bulletin "link" paper, anti-HIV therapy drug. Among the projects we sampled, $37.6 \%$ of the projects the NPD teams worked on involved a new technology, 38.3\% involved several new technologies, and $10 \%$ of the sample involved non-proven or non-existing technologies, which was consistent with what we expected to investigate at technology-based firms. Our operational definition for teams working on radical and incremental NPD appears below. The median NPD team size was 11 people, the average NPD team size was 23 people and the S.D. was 38. Most projects were from large companies: $69.6 \%$ of the projects were from companies with annual incomes over 500 million dollars, $26.8 \%$ of the projects were from companies employing 500-5000 workers, and $47.1 \%$ of the projects were from companies employing over 5000 people.

In each company, the contact person chose primarily product, senior engineering, technical and marketing managers as respondents. All these individuals were NPD team members. Participation in the study was voluntary, and the participants were assured that their responses would be kept confidential. Forty one percent of the respondents were product managers, $25 \%$ and $13 \%$ of the respondents were senior engineering or technical managers and the remainder were marketing managers, all of whom were project members. To test for differences in respondent type, one-way analyses of variance (ANOVAs) were performed with all of the major personal style constructs as dependent variables, and respondent type as the independent variable. No significant differences were found.

The respondents were instructed to choose teams who had completed an NPD project. Our sample included a range of successful and unsuccessful NPD projects, however our data were skewed toward successful projects. Some unsuccessful projects were undoubtedly not included because they were never completed. Such restriction in range tends to impact correlations more than regression weights [e.g. Aronson et al. (2006)], however, so we feel that this restriction did not seriously bias our results.

Further, to ensure a reasonably comparable level of familiarity with the NPD teams and their staff members across the sample, each respondent was asked to choose a team working on an NPD project with which he/she was intimately familiar with, and involved with throughout its development. Product development studies routinely use retrospective methods for reasons of feasibility [e.g. Meyer and Utterback (1995)]. To improve the accuracy of retrospective reports, respondents were asked by the contact person to select recent projects, to eliminate the elapsed time between the events of interest and the collection of data.

In the current sample, there was one informant per NPD team. Based on our study's empirical findings, we do not believe the respondents' retrospective assessment of the personal style of the NPD staff members, was dependent on the extent the team developing the new product met the performance criteria. Our results show there were differences in correlations between NPD staff personal style and the NPD speed and success criteria, depending on the type of NPD team. For example, the average openness of the staff was significantly associated with NPD speed for radical NPD teams only. The average agreeableness of the staff was significantly associated with NPD success for incremental NPD teams only. These findings support the argument that single respondents can provide good data. 
What is more, Klein and Kozlowski [2000] note that while multilevel models are relevant to a majority of organizational phenomena it is not always essential that they be applied. One exception cited [Klein and Kozlowski (2000)] is when researching phenomena that have been previously unexplored as in the current case.

Finally, use of self-report data is a common practice in management research, and has led to the so-called "common method variance" problem. Reviews of other research and our own data would indicate that method variance is not a significant issue in the present study. Theoretically, there are several explanations why method variance should not substantially affect our results. First, self-report data is most problematic for topics which generate strong sentiments, such as attitudes [Cote and Buckley (1987)]. New product speed and success are much less emotionally laden subjects, and hence less likely to be distorted by self-reports. Second, social desirability bias often leads to response range compression [Podsakoff and Organ (1986)] which was not evident in our sample. Third, Lukas and Ferrell [2000] and Podsakoff and Organ [1986] found that managers rely on their own self-reports and provide reliable and objective data.

\subsection{Measures}

\subsubsection{Radical versus incremental innovation}

We were interested in teams developing radical innovations and teams developing incremental innovations. Based on the work of Lynn and Akgun [1998] described earlier, staff personal style was analyzed under high uncertainty (radical innovation) and low uncertainty (incremental innovation). A measure of radical versus incremental innovation was derived based on information provided by the respondents to two items representing market and technology uncertainty. Both items were rated on a scale ranging from 0 (strongly disagree) to 10 (strongly agree) and were as follows: "The technology required to develop this product ( $\mathrm{R}$ and $\mathrm{D})$ was totally new to our company", and "This product had to be sold to people or organizations outside our company's traditional customer base". The rationale for this measure is that teams working on incremental innovation operate under more certain environments, when a currently served market with mature technologies is targeted. On the other hand, teams working on radical innovation operate under more uncertain environments, when both market and technology uncertainties are high. We were interested in the role of staff personal style in NPD performance for two types of teams: NPD teams that develop radical innovations and operate under conditions of higher uncertainty and NPD teams that develop incremental innovations and operate under conditions of lower uncertainty. Accordingly we first took the average of the two items, and then dichotomized at the scale mid-point. Consequently, the 149 NPD teams yielded 75 incremental and 74 radical NPD teams.

It is worth mentioning that there might be alternative ways to operationalize teams working on radical versus incremental innovations. The rationale for our categorization of these teams is our concern with the differing uncertainty levels these teams face, and how this might relate to the optimal team personal style characteristics needed for success in NPD project-based work. Teams working on 
radical innovations operate under more uncertain environments, when both market and technology uncertainties are high. Our operationalization for each of these teams is derived from work by Lynn and Akgun [e.g. 1998] on incremental and radical teams, and Barczak and Wilemon [e.g. 1989] on operating and innovating teams. Lynn and Akgun mention that incremental innovation exists under highly certain environments, when a currently served market with mature technologies is targeted. Radical innovation, in contrast, exists when both market and technology uncertainties are high. Operating teams are concerned with maintaining competitive positions in existing businesses and, as a result, they usually focus on incremental innovation or small improvements to current products. Innovating teams, in contrast, focus on developing a new business for the firm. They are more likely to focus on important new products for unfamiliar markets. Lynn and Akgun characterize both these teams as incremental and radical, respectively. Other researchers [e.g. Aronson et al. $(2006,2008)$ ] include the technology and the market as criteria to categorize various types of innovation teams.

\subsubsection{NPD project performance}

Our performance measure included two different criteria, NPD success and speed. The criteria were each assessed with items rated on a scale ranging from 0 (strongly disagree) to 10 (strongly agree) [Lynn et al. (2000)]. The following items were included in the success measure: this project (1) overall met or exceeded sales expectations, (2) met or exceeded profit expectations, (3) met or exceeded return on investment expectations, (4) met or exceeded overall senior management's expectations, (5) met or exceeded market share expectations, (6) met or exceeded customer expectations. Cronbach's alpha for the success measure was 0.96. We assessed NPD speed using the following items [Lynn et al. (2000)]: this project (1) was developed and launched faster than the major competitor for a similar product, (2) was completed in less time than what was considered normal and customary for our industry, (3) was launched on or ahead of the original schedule developed at initial project go-ahead, (4) top management was pleased with the time it took us from specs to full commercialization. Cronbach's alpha for the speed measure was 0.86 .

In the current study, the performance measure included NPD speed and success. Although different terms such as time-to-market, cycle time, innovation speed, and speed-to-market have been used to portray NPD speed, it generally represents how quickly an idea moves from conception to a product in the marketplace, measuring firms' capabilities to move quickly through the NPD process [Chen et al. (2005)]. By developing products quickly, companies can achieve several important benefits. First, fast NPD can increase product profitability, margins, and market share. Firms are able to translate time into profits by satisfying their "impatient" customers, who are willing to pay a premium if they can get goods and services very quickly [Brown and Eisenhardt (1995)]. Second, companies with fast NPD have a greater chance to establish industry standards and may lock up distribution channels [Dumaine (1989)]. Third, a firm with the capability of developing products rapidly can quickly respond to market demands, improving the timeliness of its product entry and 
customer satisfaction. In the current study, in addition to NPD speed, we included an indicator of NPD success [e.g. Lynn et al. (2000)], capturing customer, profitability, market share and senior management expectations.

A recent survey suggested that NPD speed is the most important metric of innovation performance [Boston Consulting Group (2006)]. In addition, NPD speed is also a key component of time-based strategy and a pivotal way to achieve time advantage, either first-mover or fast-follower advantage [Stalk and Hout (1990)]. Shenhar colleagues [2005] viewed time advantage as a new generic competitive strategy, adding it to Porter's [1985] three generic strategies of cost leadership, differentiation, and focus. This strategy provides competitive advantage by enabling firms to adapt quickly to market needs in the dynamic and competitive business context [Eisenhardt and Tabrizi (1995)]. Further, through developing products quickly, companies learn to build new competencies to differentiate themselves from competitors [Wheelwright and Clark (1992)]. For example, they will be able to choose to be a market pioneer or to consciously adopt a fast follower strategy [Emmanuelides (1993)]. Because the first-mover advantage may not always lead to enduring market leadership [Tellis and Golder (2001)], companies with fast NPD may benefit from having more strategic alternatives than the slower innovators.

Some researchers and practitioners argue that there are potential trade-offs between NPD speed and other NPD performance indicators, such as speed-quality [Calantone and Di Benedetto (2000); Harter et al. (2000)] speed-cost [Gupta et al. (1992)], and speed-success [Griffin (2002)]. For example, Lukas et al. [2002] argue that a strict deadline might make NPD teams slip key processes, trim performance specifications, and/or reduce technological content, which typically undermine product quality. Lambert and Slater [1999] contend that fast NPD may make managers focus on schedules at the expense of more resources and product performance. While there may be pitfalls to fast product development, NPD speed is viewed as a primary indicator of firm innovation performance, and is essential for the success, survival, and renewal of firms in turbulent and uncertain environments [Eisenhardt and Tabrizi (1995); Kessler and Chakrabarti (1996)]. Consequently, in the current study, we included measures of NPD speed and NPD success as performance criteria [e.g. Lynn et al. (2000)], detailed earlier.

\subsubsection{Personal style}

As part of a survey designed to measure practices supportive of team learning, development speed, and new product success [Lynn et al. (2000); Aronson et al. (2006, 2008)] five single items were developed to assess team member personality (five-item measure of the Big Five). Building on past research [e.g. Costa and McCrae (1992); Lindner (1998); McCrae and Costa (1989); Tett et al. (1991)], each item of this measure of personality was designed to measure a single Big-Five trait (Appendix A). We obtained evidence to support the construct validity of this fiveitem measure of the Big Five as follows. In one study [Lindner (1998)], 193 students responded to the five-item measure of the Big Five, Goldberg's Adjective Checklist (1992) and the NEOFFI [Costa and McCrae (1992)], all of which measure the Big-Five 
personality traits. (Note that there was no overlap in items between the three personality measures). Correlations among similar constructs between the five-item measure of the Big Five and Goldberg's Adjective Checklist were 0.67, 0.61, 0.63, 0.55, 0.66 for extraversion, agreeableness, conscientiousness, neuroticism and openness to experience respectively, providing evidence of convergent validity.

The correlations among similar constructs between the five-item measure of the Big-Five personality traits and the NEO-FFI were $0.56,0.56,0.64,0.55,0.50$, respectively. In both analyses, correlations across dissimilar constructs were much lower, providing evidence of discriminant validity. For comparative purposes, the convergent validities between the NEO-FFI and Goldberg's Adjective Checklist were very similar to the convergent validities reported above, $0.59,0.61,0.72,0.64$, 0.42 , respectively for each of the five personally traits. These results resemble those reported by other researchers. For example, Goldberg [1992] reported correlations between similar personality dimensions from a set of 100 Big-Five markers and the NEO-PI (a Big-Five personality measure [Costa and McCrae (1985)] that ranged from 0.46 to 0.69 as evidence of the construct validity of those markers. Barrick and Mount [1993] reported correlations among similar personality dimensions from the personal characteristic inventory (PCI, a Big-Five personality measure), and the NEO-PI that ranged from 0.56 to 0.71 as evidence of the construct validity of the PCI. In summary, the rather high correlations of similar constructs of the five-item measure of the Big Five with those on the NEO-FFI and Goldberg's Adjective Checklist, and the low correlations between dissimilar constructs, which are similar to those reported by other researchers, provide evidence about the construct validity of the personality measure used in the current study.

It is worth mentioning that empirical evidence supporting the construct validity of this five-item measure of the Big Five was confirmed in the current study as well.

Table 2 provides evidence of discriminant validity between the five personality variables, with generally moderate correlations between staff personal style variables, which are comparable to correlations reported elsewhere for the FFM of personality [e.g. Barrick et al. (2002); Boudreau et al. (2001)]. Additionally, in the current research, staff personal style was differentially related to this study's performance criteria, NPD speed and NPD success, providing additional support that this measure can be a useful measure of the Big-Five traits.

We followed Cohen et al.'s [2003] guidelines for measuring multicollinearity. Cohen and colleagues discuss several multicollinearity indices that can provide useful information, but they argue that these indices do not substitute for basic checks of the data. First, Cohen and colleagues recommend to carefully examine the scatter plot matrix of the predictor variables, looking for outlier observations that may affect the relationship between each pair of independent variables (IVs). Cohen and colleagues add that outliers can greatly increase or decrease the magnitude of the relationship between variables, leading to values of multicollinearity indices that may be too high or too low. Additionally, Cohen and colleagues suggest to compare the results of a simple univariate regression analysis in which the outcome (e.g. NPD performance criteria, $Y$ ) is regressed separately on all of the predictor variables of interest (e.g. personal style variables, $X$ ). We followed Cohen and colleagues' 
suggestion and we compared the correlations $(r)$ for each IV $(x y)$ with its corresponding standard $\beta$ in the regression equation. Large, unexpected changes in direction and magnitude of these coefficients would have suggested a substantial influence of multicollinearity. In our examination, we did not find large changes in direction and magnitude of these coefficients, which suggests that we did not have substantial influence of multicollinearity.

The NPD professionals in the current study rated the NPD team staff's personal style, using the five-item measure of the Big Five, on a scale from 1 to 5 (Appendix A). Justification for using observer ratings of personal style can be found in past research [Aronson (1998); Mount et al. (1994)]. Observers' assessments of other staff's personal style are at least as valid as self-assessments, because they are based on observations of these individuals, almost exclusively in the work environment. On the other hand, individuals (NPD staff members) see themselves in numerous situations, such as at home, at play, and at work. Consequently, self-ratings of personal style have less point-to-point correspondence between the predictor and the criterion. An operational definition of each of the FFM personal style variables was provided (e.g. "Extroversion-Introversion: the extent to which team members are sociable, talkative, assertive, active (Extroverted) versus retiring, sober, reserved, cautious (Introverted)". The responding NPD professionals were asked to distribute the percentage of NPD staff members into each of five categories ranging from high on one end of a bipolar scale (e.g. Highly Extraverted) to high on the other end (e.g. Highly Introverted). This procedure allowed to calculate the mean and standard deviation for the project team on each of the FFM personal style variables.

\section{Results}

The means and standard deviations for all staff personal style variables (e.g. Conscientiousness AVG, Agreeableness AVG, etc.) for incremental and radical NPD teams are presented in Table 1. No significant differences existed between the two types of NPD teams, with respect to all staff personal style variables. The intercorrelations between all five staff personal style variables for all NPD teams and NPD speed and success are reported in Table 2. As shown, for NPD speed, the

Table 1. Means and standard deviations of all variables for incremental and radical NPD teams.

\begin{tabular}{lcccccc}
\hline & \multicolumn{2}{c}{ Incremental } & & \multicolumn{2}{c}{ Radical } & \\
\cline { 2 - 3 } Variable & $\mathrm{M}$ & $\mathrm{SD}$ & & $\mathrm{M}$ & $\mathrm{SD}$ & \\
\hline Speed & 6.67 & 2.42 & & 6.16 & 2.67 & 1.21 \\
Success & 6.74 & 2.90 & & 5.79 & 2.80 & $2.02^{*}$ \\
Extraversion AVG & 3.54 & 0.63 & & 3.58 & 0.70 & -0.29 \\
Agreeableness AVG & 3.86 & 0.57 & & 3.86 & 0.65 & -0.02 \\
Conscientiousness AVG & 4.33 & 0.49 & & 4.29 & 0.64 & 0.49 \\
Stability AVG & 4.14 & 0.66 & & 4.20 & 0.65 & -0.46 \\
Openness AVG & 4.00 & 0.67 & & 4.10 & 0.59 & -0.94 \\
\hline
\end{tabular}

Note: ${ }^{*} p<.05$. Incremental: $n=75$, radical: $n=74, \mathrm{AVG}=$ average. 
Table 2. Correlations between staff personal style variables and NPD performance criteria.

\begin{tabular}{|c|c|c|c|c|c|c|c|}
\hline Variable & 1 & 2 & 3 & 4 & 5 & 6 & NPD success \\
\hline 1. Extraversion AVG & & $0.40^{* *}$ & $0.37 * *$ & $0.21^{* *}$ & $0.44^{* *}$ & $0.19^{*}$ & 0.13 \\
\hline 2. Agreeableness AVG & & & $0.45^{* *}$ & $0.58^{* *}$ & $0.57^{* *}$ & $0.28^{*}$ & $0.34^{* *}$ \\
\hline 3. Conscientiousness AVG & & & & $0.53^{* *}$ & $0.59^{* *}$ & $0.27 * *$ & $0.31^{* *}$ \\
\hline 4. Stability AVG & & & & & $0.51^{* *}$ & $0.23^{* *}$ & $0.23^{* *}$ \\
\hline 5. Openness AVG & & & & & & $0.16^{*}$ & $0.20^{*}$ \\
\hline 6. NPD speed & & & & & & & $0.56^{* *}$ \\
\hline
\end{tabular}

Note: ${ }^{*} p<0.05$ (2-tailed), ${ }^{* *} p<0.01$ (2-tailed), AVG = average.

magnitude of the correlations for staff conscientiousness, agreeableness and emotional stability were $0.27,0.28$ and $0.23(p<0.01,2$-tailed) respectively, and for openness and extraversion the correlations were 0.16 and 0.19 ( $p<0.05,2$-tailed). For NPD success, the magnitude of the correlations for staff conscientiousness, agreeableness and emotional stability were $0.31,0.34$, and $0.23(p<0.01,2$-tailed $)$ respectively, and for openness and extraversion the correlations were 0.20 and 0.13 $(p<0.05 ; p<0.1,2$-tailed). Table 2 provides evidence of discriminant validity between the five personal style variables. As shown, the personal style of the staff was differentially related to this study's NPD speed and success criteria, and the generally moderate correlations between staff personal style variables provide additional support that this measure can be a useful measure of the Big-Five traits.

The correlations between staff personal style variables and NPD speed for incremental and radical innovation teams are provided in Table 3. As hypothesized, the correlations with NPD speed were significantly higher when innovation was radical only for staff openness $(r=0.32, p<0.01,2$-tailed) and emotional stability $(r=0.36, p<0.01,2$-tailed), as the slope tests, detailed in the Hierarchical regression analysis, reveal below. The correlations between staff personal style variables and NPD success for incremental and radical innovation teams are provided in Table 4. As hypothesized, the correlations with NPD success were significantly higher when innovation was incremental only for staff agreeableness $(r=0.53, p<0.01,2$-tailed) as illustrated in the slope tests described next.

Hierarchical regression analyses were performed to test whether the regression lines for staff personal style and NPD speed and success were significantly different, for radical versus incremental innovation. A dummy variable was created to

Table 3. Correlations between staff personal style and NPD speed for incremental and radical projects: $F$-test of slopes.

\begin{tabular}{lccc}
\hline & Incremental & Radical & $F$-Test of slopes \\
\hline Extraversion AVG & 0.08 & $0.27^{*}$ & 1.36 \\
Agreeableness AVG & 0.20 & $0.33^{* *}$ & 0.62 \\
Conscientiousness AVG & 0.12 & $0.37^{* *}$ & 1.61 \\
Stability AVG & 0.08 & $0.36^{* *}$ & $3.45^{+}$ \\
Openness AVG & 0.02 & $0.32^{* *}$ & $4.52^{*}$ \\
\hline
\end{tabular}

Notes: ${ }^{*} p<0.05$ (2-tailed), ${ }^{* *} p<0.01$ (2-tailed), $+p<0.10$ (2-tailed). Incremental: $n=75$, radical: $n=74, \mathrm{AVG}=$ average. 
Table 4. Correlations between staff personal style and NPD success for incremental and radical projects: $F$-Test of slopes.

\begin{tabular}{lccc}
\hline & Incremental & Radical & $F$-Test of slopes \\
\hline Extraversion AVG & 0.21 & 0.10 & 1.24 \\
Agreeableness AVG & $0.53^{* *}$ & 0.17 & $7.28^{*}$ \\
Conscientiousness AVG & $0.35^{* *}$ & $0.26^{*}$ & 1.33 \\
Stability AVG & $0.33^{* *}$ & 0.14 & 1.55 \\
Openness AVG & $0.24^{*}$ & 0.18 & 0.05 \\
\hline
\end{tabular}

Note: ${ }^{*} p<0.05$ (2-tailed), ${ }^{* *} p<0.01$ (2-tailed), AVG = average.

represent radical versus incremental innovation and cross-product terms were computed by multiplying this dummy variable by each of the five-factor personal style scores for each NPD type. The slopes and intercepts of the regression lines were compared for each of the staff personal style variables. For NPD speed (Table 3), the slope tests for staff openness showed a significant difference for radical versus incremental NPD supporting hypothesis 3 , and a marginally significant difference for emotional stability, providing support for hypothesis 4. As hypothesized, for NPD speed, the slopes of the regression lines were significantly higher for staff openness when innovation was radical $(F=4.52, \mathrm{df}=1,145, p<0.05,2$-tailed). For NPD speed, the slopes of the regression lines were marginally higher for staff emotional stability when innovation was radical $(F=3.45$, df $=1,145, p<0.10,2$ tailed). As hypothesized, for NPD success (Table 4), the slopes of the regression lines were significantly higher for staff agreeableness when innovation was incremental ( $F=$ 7.28 , df $=1,145, p<0.05,2$-tailed).

Finally, a multiple regression analysis was conducted using NPD speed and NPD success as the dependent variables to test which of the staff personal style variables was most important for the NPD performance criteria. Table 5 shows the beta weights and multiple correlation, between all FFM personal style variables and the NPD performance criteria, speed and success. Conscientiousness and agreeableness had the highest beta weights. For example, for NPD success, the beta weight for staff conscientiousness and agreeableness were significant at the $p<0.05$ and $p<0.01$ levels correspondingly ( $\beta=0.25$ and 0.32 respectively), supporting hypotheses 1 and 2. Similar findings are reported in Table 5 for the NPD speed criterion. For NPD speed, the beta weights for staff conscientiousness and agreeableness were marginally significant at the $p<0.10$ level $(\beta=0.21$ and 0.20$)$. Overall, for the NPD project performance criteria, staff personal style variables had a multiple correlation of $R=0.35$ and 0.40 for the speed and success criteria respectively, indicating support for measuring staff personal style variables using the FFM model. Our findings are in line with recent meta-analytical research on personality and team performance [e.g. Peeters et al. (2006)]. Results illustrate the importance of considering personal style, in addition to functional expertise, when assigning employees to innovation teams [e.g. Atuahene-Gima (2003); Brown and Eisenhardt (1995); Chen et al. (2010); Hoegl et al. (2004); Keller (2001); Zirger and Hartley (1994)].

It is noteworthy that Cohen [e.g. 1988] mentions that judging whether a Pearson correlation coefficient $r$ is strong, moderately strong or weak depends on the context 
Table 5. Multiple regression: Beta weights and multiple correlations for staff personal style variables and NPD speed and success.

\begin{tabular}{lcc}
\hline & $\beta$ Speed & $\beta$ Success \\
\hline Extraversion AVG & 0.08 & -0.04 \\
Agreeableness AVG & $0.20^{+}$ & $0.32^{* *}$ \\
Conscientiousness AVG & $0.21^{+}$ & $0.25^{*}$ \\
Stability AVG & 0.05 & -0.04 \\
Openness AVG & -0.14 & -0.11 \\
$R$ & 0.35 & 0.40 \\
$F$-test of $R^{2}$ & $3.66^{* *}$ & $5.08^{* *}$ \\
\hline Note: $\quad{ }^{*} p<0.05, \quad{ }^{* *} p<0.01$, & ${ }^{+} p<0.10$, \\
AVG $=$ average. & &
\end{tabular}

in which the correlation has been computed. Within the behavioral sciences, and applied psychology, the criteria for evaluating the strength of the correlations were first introduced by Cohen [Cohen et al. (2003)]. These criteria, detailed below, are now widely used in behavioral sciences research, including individual differences studies, similar to the assessments we ran in the current research. According to the criteria [e.g. Cohen (1988)] often cited, a correlation $= \pm 0.50$ is considered a strong correlation in the behavioral sciences, a correlation of \pm 0.30 is considered a moderate correlation, and a correlation of \pm 0.10 is considered weak. Cohen's classification that a correlation of 0.50 is considered a strong correlation comes from the assertion that in applied social psychology and behavioral sciences, high correlations, e.g. 0.50 and above are achieved only when the correlations are measures of reliability. Cohen provides examples of correlations that are 0.82 , which is classified as a strong correlation, and 0.32 , which is classified as a moderately strong correlation between two variables. Yet, both these correlations are considered typical correlations in their respective contexts, e.g. in the behavioral sciences, note Cohen and colleagues. In our study for example, four of the five individual differences correlations for radical NPD speed reported in Table 3 are above 0.30; they are $0.33,0.37,0.36,0.32$, the final correlation is 0.27 . The average correlation is 0.33 across all five personal style differences, which is above Cohen's benchmark of 0.30 , for moderately strong correlations. In our study, three of the five individual differences correlations for incremental NPD success reported in Table 4 are above 0.30 ; they are $0.53,0.35,0.33$, and the final two correlations are 0.24 and 0.21 . The average correlation is 0.33 across all five personal style differences, which is above Cohen's benchmark of 0.30 , for moderately strong correlations as well.

\subsection{Project management activities and the relevance of diverse team personality traits}

We conducted a series of post-hoc analyses, to identify team personality traits that have relevance to possible project management activities using additional limited qualitative data we had. For example, results (Table 6) illustrate that team conscientiousness was germane to several recording and filing behaviors (data gathering/ 
Table 6. Qualitative information: Different project management activities and the relevance of diverse personality traits of team members.

Project members' activities

Data gathering/information management
Team member personality

$\begin{array}{lllll}\text { E } & \mathrm{A} & \mathrm{C} & \mathrm{S} & \mathrm{O}\end{array}$

Action items resulting from team staff meetings were regularly recorded

Technical quality prototype test results were proficiently recorded

Overall, most information relating to this project was proficiently recorded

Information collected by the team (e.g. test results) was coded and sorted to be understood easily by other team members

A central file on this project was kept that included initial concepts, engineering specs, prototype protocols, and customer input/reaction to early concepts

Project information was stored on a computer-based information system

Past project reviews were filed with the central project file $\mathrm{X}$

During the project, the NPD process (from concept through launch) was continuously analyzed

Project direction

The overall business goals were clear

The technical goals were clear

The team had a clear understanding of target customers' needs and wants

The team followed a clear plan — a roadmap with measurable milestones

Conflict management

Team members acknowledged conflict and worked to resolve issues on the team

Team members encouraged diverse perspectives and differing points of view from others on the team

Meaningful information was gathered

Market information was summarized to reduce its complexity

Market information was organized in meaningful ways

Technical information was summarized to reduce its complexity

Technical information was organized in meaningful ways

Creative problem solving

Team members practiced what-if analysis extensively to understand possible market and technical scenarios

Information captured on customers' needs and wants was shared quickly throughout the team

Test results on this product were shared quickly throughout the team

Teamwork behaviors: coordination/information and knowledge Sharing

Team members helped others on the team by sharing knowledge and information

Team members were working together toward a unified goal

Team members would freely share information (technical, market, etc.) with others on the team

Team members demonstrated interest and enthusiasm during team activities

Team members acknowledged the contributions made by others on the team

$\begin{array}{lll}\sqrt{ } & \sqrt{ } \\ & \sqrt{ } \\ & \sqrt{ } \\ \sqrt{ } & \sqrt{ } \\ & \sqrt{ } & \sqrt{ } \\ & \\ & \\ & \sqrt{ } \\ \sqrt{ } & \sqrt{ } \\ & \sqrt{ } \\ & \\ & \sqrt{ } \\ & \sqrt{ } \\ & \sqrt{ } \\ \sqrt{ } & \sqrt{ } \\ \sqrt{ } & \end{array}$

$\sqrt{ }$

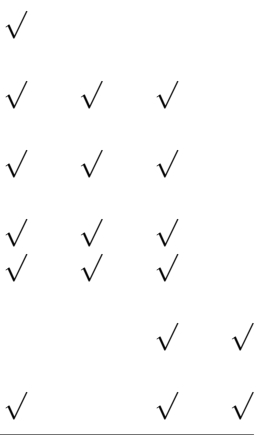

Note: A: agreeableness, C: conscientiousness, E: extraversion, S: stability, O: openness.

information management), whether the NPD process was continuously analyzed, and to whether the team followed a clear plan — a roadmap with measurable milestones (project direction). These behaviors should help project members to be attentive to the plan and engender these members to work together toward project 
goals. Furthermore, team member agreeableness was pertinent to whether information captured on customers' needs and wants was shared (project member information sharing). Such info sharing can help NPD staff members to catch downstream problems such as manufacturing difficulties, before these happen, when the problems are generally smaller, easier to remedy and perhaps also consume less project time. Additionally, team member openness was relevant to whether market and technical information was organized and summarized in meaningful ways to reduce complexity (meaningful information was gathered), whether team members acknowledged conflict and worked to resolve issues on the team (conflict management) and to creative problem solving. These behaviors should help members encourage and handle new ideas that are necessary for innovations. These team personality traits and the remaining factors (stability and extraversion) were differentially related to project management activities including coordination/information and knowledge sharing, as hypothesized.

\section{Discussion}

In the current research, we centered on testing the effect of staff personal style on NPD project performance. As we hypothesized, in particular, two staff personal style variables appear to be most valuable in their influence on NPD performance. Agreeableness and conscientiousness have the highest correlations with NPD speed and success and the highest beta weights when all personal style variables are entered into a multiple regression equation. The present results for agreeableness and conscientiousness are consistent with earlier studies [e.g. Barrick et al. (1998); Hough (1992); Kichuk and Wiesner (1997); Neuman and Wright (1999)]. These findings are in line with recent meta-analytical research on personality and team performance [e.g. Peeters et al. (2006)].

Yet, our examination shows that when considering the type of innovation the teams are working on, the relationship between staff personal style variables and NPD performance criteria varies. The slope comparisons between incremental and radical innovation teams with speed as a dependent variable yielded a significant difference for openness and a marginally significant difference for stability. Openness is more highly correlated with speed when innovation is radical suggesting that having a team more apt to consider new ideas will speed up the process when new, breakthrough ideas are being developed. A more stable team may also contribute to speed when innovation is radical. Less stable team members might be disruptive in meetings and perhaps have higher absenteeism, for example, both of which would slow progress.

With success as the dependent variable a significant difference in slopes was found for staff agreeableness. Having team members who are agreeable does not appear to be important when new ideas are being developed. It could be that high levels of agreement lead to "groupthink" or failure to challenge ideas as frequently, conceivably leading to less successful innovation. Our findings add to the literature [e.g. Atuahene-Gima (2003); Brown and Eisenhardt (1995); Chen et al. (2010); Hoegl et al. (2004); Keller (2001); Zirger and Hartley (1994)] on the value of considering 
personal style, in addition to functional expertise, when assigning employees to innovation teams.

\subsection{Understanding the value of staff personal style for NPD performance}

Findings suggest that when it comes to NPD project performance, the level of staff conscientiousness tends to be important (Tables 2 and 5). Staffing NPD teams with conscientious employees might reduce the likelihood of social loafing, which could affect the extent the NPD project is developed and launched faster than the major competitor for a similar product, conceivably meeting market share and overall senior management's expectations. Other investigators' findings are consistent with this contention [e.g. Brown and Eisenhardt (1995); Gemünden et al. (2005)]. What is more, because conscientious individuals tend to be dedicated to implementing multiple role requirements of teams, NPD teams composed of conscientious staff members might conceivably concentrate on fulfilling the needs of the team, possibly affecting the success and the pace in which the NPD project is implemented. Scholars agree with this assertion and illustrate that conscientiousness predicts performance outcomes across job categories and criteria [e.g. Barrick and Mount (1993)]. Aligned with our findings, researchers [e.g. Keller (1997)] demonstrate that conscientiousness should be predictive of $R \& D$ performance in general for scientists and engineers.

Results also show that the level of NPD staff on agreeableness might be important for NPD project performance (Tables 2 and 5). Agreeable people are inclined to be sympathetic to others, willing to support, and believe that others will be helpful in return. Supportive staff members might inform each other about non-routine demands, allowing them to take steps to mitigate problems, contributing to completion of the NPD project on schedule. NPD project participants who disseminate their functional expertise to fellow staff members could expose their associates to diverse information. Such increased information sharing could further help NPD staff members to catch downstream problems such as manufacturing problems or marketing discrepancies, before they happen, when these challenges are generally easier to fix [Brown and Eisenhardt (1995); Katz and Tushman (1981)], and perhaps also consume less project time. It is plausible that NPD staff who support one another would not have to turn to their project managers for help, leaving the project managers free to complete more important tasks, such as obtaining personnel and financial support, resulting in the NPD project achieving its goals and satisfying customer expectations. Further, in the challenging project-based work context, in which resources and goals are uncertain and customer demands are changing, the less time project participants spend complaining or finding fault with project colleagues, the more time these agreeable individuals can devote to more productive purposes, perhaps affecting the time it takes from specs to full commercialization.

Interestingly, when considering the type of innovation the teams are working on, the relationship between staff personal style and NPD performance criteria might vary. Our examination shows when it comes to NPD speed, radical NPD teams might benefit from staff members that are more open (Table 3). It might be easier for open staff members to encourage and handle new ideas that are necessary for radical 
innovations. Radical NPD frequently involves a great deal of learning and improvising. The need to learn more about the markets and the technical issues necessary to successfully bring the product to market on time is likely to make the openness of the staff members a desirable personal style trait.

Open staff members may also play a role in fostering, processing and disseminating information necessary to handle the uncertainty facing radical NPD teams. Open individuals tend to be open to new ideas and information [Costa and McCrae (1992)] and open NPD staff could plausibly be open to new information whether it is from purchasing, vendor management, or the customer. NPD staff members who are open to new information from the consumer, could conceivably develop products that are perceived as new or, different to existing products, or develop a completely new product that is acceptable in the market, faster than key competitors. More open staff members might also be more creative when it comes to suggesting novel strategies for obtaining resources, such as needed talent, and larger budgets for the team [Brown and Eisenhardt (1995)], which in turn could conceivably help reduce the time it takes to complete the NPD project.

When innovations are radical, development teams face other severe challenges because the market is not well understood and the product is still evolving and changing with the market. Radical innovations require a focus on a learning-based strategy. Product teams try a product in the market to learn, improve it, and try it again [e.g. Lynn et al. (1996)]. Our results suggest that NPD staff high in openness might be more likely to be successful on, for example, "trial and error research tasks", among others, which, in turn, may involve maintaining flexibility and learning through experience, as well as other types of learning (e.g. observational learning), possibly resulting in launching the NPD project at or ahead of the original schedule.

Our examination also shows that the emotional stability of NPD staff members may be helpful during radical NPD (Table 3). Radical NPD encounters many more surprises than the incremental type. Having radical NPD staff who are more emotionally stable, and who do not waste time becoming frustrated as a result of the rapid change involved with radical innovation could be beneficial. Our results suggest that NPD teams comprised of more emotionally stable staff may be more likely to, for example, buffer the radical NPD team from the stress associated with the changes, perhaps helping the team to continue functioning together over long periods of time, which might facilitate the completion of the radical NPD project on schedule. Researchers [e.g. Watson and Tellegen (1985); Barrick et al. (1998)] illustrate that higher levels of team emotional stability should contribute to a relaxed atmosphere and to team viability, which is consistent with this contention. Emotional stability may be relatively insignificant in distinguishing between success and failure when it comes to the speed an incremental NPD project is completed, since the staff are working under conditions that are more certain. Although this argument might seem to depart from meta-analytical results [e.g. Salgado (1997, 2002)] that emotionally stable employees, including NPD employees, are likely to have higher levels of job performance, which could include completing NPD projects on schedule, these meta-analyses did not differentiate between, e.g. radical and incremental NPD teams. Similarly, notwithstanding the limitations of our study, 
we contend that a threshold level of staff emotional stability may be important for incremental NPD teams but may not differentiate success from failure, in terms of the speed the NPD project is completed. Yet, the level of staff emotional stability beyond the threshold level might have a significant relationship with the speed the radical NPD project is completed.

Finally, with success as the dependent variable, having team members who are high on agreeableness might not be helpful when new ideas are being developed (Table 4). It could be that high levels of agreement lead to failure to challenge ideas as frequently, leading to less successful innovation. When innovation is incremental, teams are given clear, detailed objectives, less debate is necessary and team members are able to organize the issues and accomplish their tasks. NPD staff members who are less agreeable could plausibly bring about task related conflict and deliberation which may not be helpful, given that project goals are clear. On the other hand, radical innovation might benefit from staff members who are less agreeable, in that, these individuals could conceivably foster the needed task related conflict. In fact, more agreeable staff who tend to be less conflictual, might, for example, inhibit the development of breakthrough ideas necessary for radical NPD. Our assertion is in line with the views of other researchers [e.g. Amason (1996); Janis (1972); Jehn (1995); McCrae and Costa (1989)].

\subsection{Limitations and future research}

As always is the case, there are reasons to exercise care in generalizing from any one study. There are a few limitations that should be addressed in future research. First, in the current study single-source methodology was employed. Aviolo et al. [1991] note that, studies employing single-source methodology may be biased by artificially high intercorrelations because of an overall positive, or negative, response bias. Aviolo and colleagues emphasize, however, that simply assuming that single-source data are less valid than multi-source data is overly simplistic, advancing our argument presented in the method section. In addition, much of the research on the effect of single-source bias has been done with instruments that involve social perception. While it is not our intent to minimize the potential effects of response bias, the kinds of information sought in the present survey with respect to NPD speed and success tended to be more objective in nature than many surveys used in research in the social sciences. Implicit theories, cognitive schema [e.g. Aronson and Reilly (2006)], and other cognitive frameworks applied by respondents to social-perceptual stimuli may not apply to the same extent with our survey. Thus, responding to questions regarding NPD speed and NPD success should be based on more objective data. In addition, our data support the relative lack of response bias. Our results show that the personal style constructs are differentially related to the NPD performance criteria, speed and success. What is more, as we report in the results section, we tested for multicollinearity [Cohen et al. (2003)], and we did not find substantial influence of multicollinearity.

Yet, future research could obtain archival data for some variables such as NPD speed and success as objective measures. Further, data for a single NPD team could 
be gathered from multiple sources. Personal style measures could be provided by the NPD team staff, and NPD performance ratings could be provided by the customer or senior managers. Another variation of this approach is to obtain complete data from multiple sources so that the inter-rater reliability and response bias issues can be directly examined.

Second, the procedure used to gather data on the NPD staff personal style may have weakened the magnitude of some of the validities that we found. However, empirical evidence supporting the construct validity of this five-item measure of personal style traits has been provided [Lindner (1998)], supported in the current study (Table 2) and the discriminant validity results are comparable with results reported elsewhere for the FFM [e.g. Barrick et al. (2002); Boudreau et al. (2001)]. The validities obtained between NPD staff personal style and NPD project performance are similar to the validities reported in the literature [e.g. Peeters et al. (2006)].

Moreover, our study suggests the potential usefulness of this five-item personality measure for researching questions on NPD team personal style and performance relations. Most inventories assessing personal style are lengthy. The five-item personal style measure allowed us to gather data and conduct comparisons between specific NPD staff personal style traits, and NPD speed and success for teams working on different innovations. Gathering this data from busy NPD professionals would be challenging using lengthy personality inventories. By combining the fiveitem personal style measure with data on the criteria and type of innovation the NPD team is working on, we were able to substantiate the staff personal style NPD success and NPD speed link. In short, we were able to provide answers to some difficult theoretical questions because of our use of an alternative tool for personal style assessment.

Third, in the current study, there was limited statistical power, especially in the comparisons between slopes. Statistical power for each test was limited by two factors: one is the within-group sample sizes, and second is the operational definition for teams working on radical and incremental innovation used in the present study. We are aware that there are alternative ways to operationally define teams working on radical and incremental innovations. Yet, the rationale for our categorization of these teams was our concern with the differing uncertainty levels these teams face, and how this might relate to the optimal team personal style characteristics needed for success in NPD project-based work. Teams working on radical innovations operate under more uncertain environments, when both market and technology uncertainties are high. Our operationalization for each of these teams was derived from earlier work by Lynn and Akgun [e.g. 1998] on incremental and radical teams, and Barczak and Wilemon [e.g. 1989] on operating and innovating teams. Lynn and Akgun mention that incremental innovation exists under highly certain environments, when a currently served market with mature technologies is targeted. Radical innovation, in contrast, exists when both market and technology uncertainties are high. Operating teams are concerned with maintaining competitive positions in existing businesses and, as a result, they usually focus on incremental innovation or small improvements to current products. Innovating teams, in contrast, focus on 
developing a new business for the firm. They are more likely to focus on important new products for unfamiliar markets. Lynn and Akgun characterize both these teams as incremental and radical, respectively. Other researchers [e.g. Aronson et al. (2006, 2008)] include the technology and the market as criteria to categorize various types of innovation teams. Finally, future research conducted with larger samples, would allow the formation of more extreme groups leading to stronger findings for the comparisons of slopes.

Fourth, in this study, results show that conscientiousness and agreeableness are correlated with NPD performance criteria, speed and success. Future research could be designed to create empirical conditions for inferring causality [Cohen et al. (2003)], versus reciprocal causation or mutual causation by a third variable. Cohen and colleagues describe three conditions that need to hold to show that variable $X$ (e.g. conscientiousness) may be a cause of another variable $Y$ (e.g. NPD performance): 1 . Relationship: $X$ is correlated with $Y ; 2$. Temporal precedence: $X$ precedes $Y$ in time; 3 . Non-spuriousness: The $X-Y$ relationship holds even when the influences of other possible variables on this relationship are eliminated so that the effect can be said to have been isolated. In the current study, in terms of relationship (condition 1), there is a nonzero association between $X$ and $Y$ (e.g. conscientiousness and NPD performance). However, future research could establish temporal precedence (condition 2), by gathering data on staff personal style variables at time 1 , and NPD performance data at time 2 using a longitudinal research design. Yet, it is noteworthy that Cohen and colleagues add that temporal precedence could be established on the basis of theory as well. Interestingly, several meta-analyses report that, for example, conscientiousness is related to performance outcomes across jobs [e.g. Barrick and Mount (1991); Barrick et al. (2001); Salgado (1997)]. Researchers also show that agreeableness is vital in team-based contexts [e.g. Aronoff and Wilson (1985); Costa and McCrae (1989)]. Finally, to establish non-spuriousness, these future longitudinal studies could be designed to remove the influence of possible extraneous factors that may affect the outcome variable, NPD performance. Taken together, future research designed in this way can strengthen the empirical conditions for inferring causality.

Fifth, future investigations might also explore narrow personality traits (e.g. autonomy, tough-mindedness, optimism, team-mindedness). Research suggests that there is incremental validity of narrow traits above and beyond the Big-Five traits [e.g. Dudley et al. (2006)]. Yet, interestingly, it seems that the degree to which the narrow traits contribute depends on the particular performance criterion and occupation in question. Upcoming studies could investigate the contribution of narrow personal style traits to performance for NPD professionals working in radical and incremental innovation teams.

Sixth, although other models of individual difference styles exist, such as Holland's Vocational Interests, recent meta-analyses reveal the overlap with the BigFive Personal style factors [e.g. Larson et al. (2002)]. Larson and colleagues examine the overlap of the three most widely used measures of Holland's big six domains of vocational interest, namely the Self-directed Search [Holland (1985a)], the Strong Interest Inventory [Hansen and Campbell (1985); Harmon et al. (1994)], and the 
Vocational Preference Inventory [Holland (1985b)], with the Big-Five Personal Style Factors. Larson and colleagues show the similarity between Holland's Vocational Interests and the Big-Five Personal Style Factors respectively for artistic-openness to experience, enterprising-extraversion, social-extraversion, investigative-openness, and social-agreeableness.

Seventh, it is noteworthy that some personal styles might change throughout long term projects, by experience or over other lengthy periods of time. Although a couple of personality factors, such as agreeableness and conscientiousness, tend to increase over long periods of time between ages 20 and 60, little change occurs in other personal styles, such as openness-to-experience, a key personality style we centered on, among people over the ages of 20 [e.g. Whetten and Cameron (2016)]. In the current study, NPD project members' age was over 20 years. Nevertheless, future research might gather additional information on the duration of the long-term projects and collect more data on team members' personal style at project initiation as well as at the conclusion of the project, in order to control for possible changes in team member individual differences.

Eighth, future studies might examine other variables (e.g. values) that could mediate the relationship between staff personal style and NPD performance. For example, Open staff members are open to new ideas, emphasize the importance of seeking differing perspectives when solving problems, use non-traditional thinking to deal with traditional problems and are open to criticism. These behaviors are central to norms and values associated with an adaptive culture [Aronson and Lechler (2009); Kotter and Heskett (1992)], and in turn should influence NPD performance when uncertainty is high.

\subsection{Practical implications}

For organizations, the decision to develop innovations carries significant implications. One implication is for firms to consider measuring the personal style of their NPD professionals, in addition to considering their functional expertise. Once this is done, companies might use the personal style assessments to make selection decisions when assigning employees to NPD teams. For example, it makes sense that organizations establish threshold levels of conscientiousness for employees who are being considered to be a part of NPD teams. Additionally, minimum levels of agreeableness might be established as selection criteria for these individuals, detailed earlier. Our findings also show that depending on the type of innovation, certain personal style variables might be more important for NPD performance. The current study's results might imply that selecting NPD staff members who are high on openness and emotional stability can be important when innovation is radical, and could differentiate between successful and unsuccessful NPD projects when it comes to the speed the NPD project is completed. What is more, it seems that having NPD staff members who are high on agreeableness does not appear to be important when new ideas are being developed, since it could lead to failure to challenge ideas as frequently, leading to less successful innovation. These highly agreeable individuals could be counseled, as elaborated below, to recognize situations where challenging 
the status quo is beneficial even though it may be contrary to their highly agreeable nature. It is noteworthy that our sample for radical and incremental NPD showed no significant difference in means for any of the staff personal style variables, suggesting that there might be considerable room for improvement, by using personal style in addition to functional expertise to assign employees to different types of NPD teams.

A second type of application is developmental in nature. An understanding of the personal style characteristics of staff assigned to NPD teams should allow superior developmental planning and coaching of these employees. For example, highly open staff members could be selected to be a part of a radical NPD team, operating under conditions of uncertainty. Since radical NPD frequently involves a great deal of learning and improvising, the selected employees who are high on openness can be trained to use this asset to learn more about the markets and the technical issues necessary to successfully bring the product to market in a timely fashion. Given that NPD teams need to obtain resources such as necessary talent, and larger budgets for the team, open individuals could be guided to use their skill to suggest novel strategies for obtaining these resources, perhaps helping to reduce the time it takes to complete the NPD project. These highly open individuals can also be coached to use their strength on trial and error research tasks that require maintaining flexibility and learning through experience, conceivably resulting in successfully launching the radical NPD project at or ahead of schedule.

\subsection{Conclusion}

This study contributes to our knowledge of NPD staff, in that it demonstrates relationships between the Big-Five personal style traits and NPD performance, for teams developing radical and incremental innovations. The current study provides evidence that, for NPD staff members, threshold levels of conscientiousness and agreeableness can be important for NPD performance. Our data also suggest that considering the type of innovation, certain staff personal style variables may be more valuable than others, depending on the specific NPD performance criteria. For NPD speed, our findings suggest that radical NPD might benefit from more open and stable staff. Furthermore, having team members who are highly agreeable does not seem to be helpful when new ideas are being developed, since it could lead to groupthink, leading to less successful innovation. It is notable that our sample for radical and incremental NPD showed no significant difference in means for any of the staff personal style variables, suggesting that there might be considerable room for improvement, by using personal style in addition to functional expertise to assign employees to different types of NPD teams.

\section{References}

Altman, I. and Haythorn, W. W. (1967). The effects of social isolation and group composition on performance. Human Relations, 20: 313-340.

Amason, A. C. (1996). Distinguishing the effects of functional and dysfunctional conflict on strategic decision making: Resolving a paradox for top management teams. Academy of Management Journal, 39, 1: 123-148. 
Ansoff, H. I. (1965). Corporate Strategy. McGraw-Hill, New York.

Ansoff, H. I. (1988). The New Corporate Strategy. John Wiley and Sons, New York.

Aronoff, J. and Wilson, J. P. (1985). Personality in the Social Process. Erlbaum, Hillsdale, NJ.

Aronson, Z. H. (1998). The validities of situationally framed personality ratings: An examination of self and peer ratings. Doctoral Dissertation, Stevens Institute of Technology, Hoboken, NJ.

Aronson, Z. H. and Lechler, T. (2009). Contributing beyond the call of duty: The role of culture in fostering citizenship and success in project-based work. RED Management, 39, 5: 461-480.

Aronson, Z. H. and Reilly, R. R. (2006). Personality validity: The role of schemas and motivated reasoning. International Journal of Selection and Assessment, 14, 4: 372-380.

Aronson, Z. H., Reilly, R. R. and Lynn, G. S. (2006). The impact of leader personality on NPD teamwork and performance: The moderating role of uncertainty. Journal of Engineering and Technology Management, 23: 221-247.

Aronson, Z. H., Reilly, R. R. and Lynn, G. S. (2008). The role of leader personality in new product development success: An examination of teams developing radical and incremental innovations. International Journal of Technology Management, 44, 1/2: 5-27.

Atuahene-Gima, K. (2003). The effects of centrifugal and centripetal forces on product development speed and quality: How does problem solving matter? Academy of Management Journal, 46, 3: 359 .

Aviolo, B. J., Yammarino, F. J. and Bass, B. M. (1991). Identifying common methods variance with data collected from a single source: An unresolved sticky issue, Journal of Management, 17: $571-587$.

Barrick, M. R. and Mount, M. K. (1991). The Big Five personality dimensions and job performance: A meta-analysis. Personnel Psychology, 44: 1-26.

Barrick, M. R. and Mount, M. K. (1993). Autonomy as a moderator of the relationship between the Big Five personality dimensions and job performance. Journal of Psychology, 78: 111-118.

Barrick, M. R., Mount, M. K. and Judge, T. A. (2001). Personality and performance at the beginning of the new millennium: What do we know and where do we go next [Special issue]. International Journal of Selection and Assessment, 9: 9-30.

Barrick, M. R., Stewart, G. L., Neubert, M. J. and Mount, M. K. (1998). Relating member ability and personality to work-team processes and team effectiveness. Journal of Applied Psychology, 83, 3: 377-391.

Barrick, M. R., Stewart, G. L. and Piotrowski, M. (2002). Personality and job performance: Test of the mediating effects of motivation among sales representatives. Journal of Applied Psychology, 87, 1: 43-51.

Barczak, G. and Wilemon, D. (1989). Leadership differences in new product development teams. Journal of Product Innovation Management, 6: 259-267.

Barczak, G. and Wilemon, D. (1991). Communications patterns of new product development team leaders. IEEE Transactions on Engineering Management, 38, 2: 101-109.

Barry, B. and Stewart, G. L. (1997). Composition, process, and performance in self-managed groups: The role of personality. Journal of Applied Psychology, 82, 1: 62-78.

Bateman, T. S. and Crant, J. M. (1993). The proactive component of organizational behavior: A measure and correlates. Journal of Organizational Behavior, 14: 103-118.

Boston Consulting Group (2006). The world's most innovative companies. Business Week Online, Special report - Innovation, April 24.

Bouchard, T. J., Jr. (1969). Personality, problem solving procedure, and performance in small groups. Journal of Applied Psychology Monograph, 53: 1-29.

Bouchard, T. J., Jr. (1972). Training, motivation, and personality as determinants of the effectiveness of brainstorming groups and individuals. Journal of Applied Psychology, 56: 324-331.

Boudreau, J. W., Boswell, W. R., Judge, T. A. and Bretz, Jr. R. D. (2001). Personality and cognitive ability as predictors of job search among employed managers. Personnel Psychology, 54, 1: 25-50. 
Brown, S. L. and Eisenhardt, K. M. (1995). Product development: Past research, present findings and future research. Academy of Management Review, 20, 2: 343-378.

Burchfield, M. (1997). Personality composition as it relates to team performance. Doctoral Dissertation, Stevens Institute of Technology, Hoboken, NJ.

Calantone, R. J. and Di Benedetto, C. A. (2000). Performance and time to market: Accelerating cycle time with overlapping stages. IEEE Transactions on Engineering Management, 47, 2: 232-244.

Chen, J., Damanpour, F. and Reilly, R. R. (2010). Understanding antecedents of new product development speed: A meta-analysis. Journal of Operations Management, 28: 17-33.

Chen, J., Reilly, R. R. and Lynn, G. S. (2005). The impacts of speed-to-market on new product success: The moderating effects of uncertainty. IEEE Transactions on Engineering Management, 52, 2: 199-212.

Cohen, J. (1988). Statistical Power Analysis for the Behavioral Sciences (2nd edn.). Erlbaum, Mahwah, NJ.

Cohen, S. G. and Bailey, D. E. (1997). What makes teams work? Group effectiveness research from the shop floor to the executive suite. Journal of Management, 23, 3: 239-290.

Cohen, J., Cohen, P., West, S. G. and Aiken, L. (2003). Applied multiple regression/correlation analysis for the behavioral science. Lawrence Erlbaum Associates, Mahwah, NJ.

Costa, P. T. and McCrae, R. R. (1985). The NEO-PI Personality Inventory. Professional manual. Psychological Assessment Resources, Odessa, FL.

Costa, P. T. and McCrae, R. R. (1989). The NEO-PI/NEO-FFI Manual Supplement. Psychological Assessment Resources, Odessa, FL.

Costa, P. T. and McCrae, R. R. (1992). Revised NEO Personality Inventory (NEO-PIR-I) and NEO Five-Factor-Inventory (NEO-FFI). Professional manual. Psychological Assessment Resources, Odessa, FL.

Cote, J. A. and Buckley, R. (1987). Estimating trait, method, and error variance: Generalizing across 70 construct validation studies. Journal of Marketing Research, 24: 315-318.

Crant, J. M. and Bateman, T. S. (2000). Proactive behavior in organizations. Journal of Management, 26: 435-465.

Crutchfield, R. S. (1955). Conformity and character. American Psychologist, 10: 191-198.

Day, D. V. and Silverman, S. B. (1989). Personality and job performance: Evidence of incremental validity. Personnel Psychology, 42: 25-36.

DeBiasio, A. R. (1986). Problem solving in triads composed of varying numbers of fielddependent and field-independent subjects. Journal of Personality and Social Psychology, 51: 749-754.

Driskell, J. E., Hogan, R. and Salas, E. (1988). Personality and group performance. Review of Personality and Social Psychology, 14: 91-112.

Driskell, J. E. and Salas, E. (1992). Collective behavior and team performance. Human Factors, 34: 277-288.

Driskell, J. E., Salas, E. and Hogan, R. (1987). Taxonomy for composing effective naval teams. (Tech. Rep. No. TR87002). Naval Training Systems Center, Orlando, FL.

Dudley, N. M., Orvis, K. A., Lebiecki, J. E. and Cortina, J. M. (2006). Meta-analytic investigation of conscientiousness in the prediction of job performance: Examining the intercorrelations and the incremental validity of narrow traits. Journal of Applied Psychology, 91, 1: 40-57.

Dumaine, B. (1989). How managers can succeed through SPEED. Fortune, 119, 4: 54-59.

Eisenhardt, K. M. and Tabrizi, B. N. (1995). Accelerating adaptive processes: Product innovation in the global computer industry. Administrative Science Quarterly, 40: $84-110$.

Emmanuelides, P. A. (1993). Towards an integrative framework of performance in product development projects. Journal of Engineering and Technology Management, 10, 4: 363-392.

Gemünden, H. G., Salomo, S. and Krieger, A. (2005). The influence of project autonomy on project success. International Journal of Project Management, 23: 366-373. 
George, J. M. and Bettenhausen, K. (1990). Understanding prosocial behavior, sales performance and turnover. Journal of Applied Psychology, 75: 698-709.

Goldberg, L. R. (1992). The development of markers of the Big Five factor structure. Psychological Assessment, 4: 26-42.

Greer, F. L. (1955). Small group effectiveness. Institute Report No. 6. Institute for Research on Human Relations, Philadelphia.

Griffin, A. (2002). Product development cycle time for business-to-business products. Industrial Marketing Management, 31, 4: 291-304.

Gurnee, H. (1937). Maze learning in the collective situation. Journal of Psychology, 3: 437-443.

Gupta, A. K., Brockhoff, K. and Weisenfeld, U. (1992). Making trade-offs in the new product development process: A German/US comparison. Journal of Product Innovation Management, 9, 1: 11-18.

Guzzo, R. A., Yost, P. R., Campbell, R. J. and Shea, G. P. (1993). Potency in groups: Articulating a construct. British Journal of Social Psychology, 32: 87-106.

Hansen, J. C. and Campbell, D. P. (1985). Manual for the SVIB-SCII (4th edn.). Stanford University Press, Stanford, CA.

Harmon, L. W., Hansen, J. C., Borgen, F. H. and Hammer, A. L. (1994). Strong Interest Inventory: Applications and Technical Guide. Stanford University Press, Stanford, CA.

Harter, D. E., Krishnan, M. S. and Slaughter, S. A. (2000). Effects of process maturity on quality, cycle time, and effort in software product development. Management Science, 46, 4: 451-466.

Haythorn, W. (1953). The influence of individual members on the characteristics of small groups. Journal of Abnormal and Social Psychology, 48: 276-284.

Hoegl, M., Weinkauf, K. and Gemuenden, H. G. (2004). Interteam coordination, project commitment, and teamwork in multiteam R\&D projects: A longitudinal study. Organization Science, 15, 1: 38-55.

Hogan, J. and Hogan, R. (1989). Noncognitive predictors of performance during explosive ordinance disposal training. Military Psychology, 1: 117-133.

Holland, J. L. (1985a). Self-Directed Search. Psychological Assessment Resources, Odessa, FL.

Holland, J. L. (1985b). Manual for the Vocational Preference Inventory. Psychological Assessment Resources, Odessa FL.

Hough, L. M. (1992). "The Big Five" personality variables-construct confusion: Description versus prediction. Human Performance, 5: 139-155.

Hurtz, G. M. and Donovan, J. J. (2000). Personality and job performance: The Big Five revisited. Journal of Applied Psychology, 85: 869-879.

Imai, K., Ikujiro, N. and Takeuchi, H. (1985). Managing the new product development process: How Japanese companies learn and unlearn. The Uneasy Alliance: Managing the Productivity-Technology Dilemma, eds. K. B. Clark, R. H. Hayes and C. Lorenz, Harvard Business School Press, Boston, pp. 937-375.

Janis, I. L. (1972). Groupthink. Houghton Muffin, Boston.

Jehn, K. (1995). A multimethod examination of the benefits and detriments of intragroup conflict. Administrative Science Quarterly, 40: 256-282.

Judge, T. A., Bono, E. J., Ilies, R. and Gerhardt, M. (2002). Personality and leadership: A qualitative and quantitative review. Journal of Applied Psychology, 87, 4: 765-780.

Karau, S. J. and Williams, K. D. (1993). Social loafing: A meta-analytic review and theoretical integration. Journal of Personality and Social Psychology, 65, 4: 681-706.

Katz, R. and Tushman, M. L. (1981). An investigation into the managerial roles and career paths of gatekeepers and project supervisors in a major R\&D facility. RED Management, 11: $103-110$.

Keller, R. T. (1986). Predictors of the performance of project groups in R\&D organizations. Academy of Management Journal, 29: 715-726.

Keller, R. T. (1997). Job involvement and organizational commitment as longitudinal predictors of job performance: A study of scientists and engineers. Journal of Applied Psychology, 82: 539-545. 
Keller, R. T. (2001). Cross-functional project groups in research and new product development: Diversity, communications, job stress, and outcomes. Academy of Management Journal, 44, 3: 547-555.

Kessler, E. H. and Chakrabarti, A. K. (1996). Innovation speed: A conceptual model of context, antecedents and outcomes. Academy Management Journal, 21, 4: 1143-1191.

Kichuk, S. L. and Wiesner, W. H. (1997). The Big Five personality factors and team performance: Implications for selecting successful product design teams. Journal of Engineering and Technology Management, 14: 195-221.

Kirkman, B. L. and Rosen, B. (1999). Beyond self management: Antecedents and consequences of team empowerment. Academy of Management Journal, 42: 58-74.

Klein, K. J. and Kozlowski, S. W. J. (2000). Multilevel Theory, Research and Methods in Organizations. Jossey-Bass, San Francisco.

Kotter, J. P. and Heskett, J. L. (1992). Corporate Culture and Performance. Free Press, New York.

Lambert, D. and Slater, S. F. (1999). Perspective: First, fast, and on time: The path to success or is it? Journal of Product Innovation Management, 16, 5: 427-438.

Larson, L. M., Rottinghaus, P. J. and Borgen, F. H. (2002). Meta-analyses of Big Six Interests and Big Five Personality Factors. Journal of Vocational Behavior, 61: 217-239.

LePine, J. A., Hollenbeck, J. R., Ilgen, D. R. and Hedlund, J. (1997). Effects of individual differences on the performance of hierarchical decision-making teams: Much more than $\mathrm{g}$. Journal of Applied Psychology, 82: 803-811.

Lindner, S. J. (1998). Generalizability and validity of behaviorally-based measurement of the Big-Five personality traits. Doctoral Dissertation, Stevens Institute of Technology, Hoboken, NJ.

Lukas, B. A. and Ferrell, O. C. (2000). The effect of market orientation on product innovation. Journal of the Academy of Marketing Science, 28: 239-247.

Lukas, B. A., Menon, A. and Bell, S. J. (2002). Organizing for new product development speed and the implications for organizational stress. Industrial Marketing Management, 31, 4: 349-355.

Lynn, G. S. and Akgun, A. E. (1998). Innovation strategies under uncertainty: A contingency approach for new product development. Engineering Management Journal, 10, 3: 11-17.

Lynn, G. S., Morone, J. and Paulson, A. (1996). Marketing and discontinuous innovation: The probe and learn process. California Management Review, 38, 3: 8-37.

Lynn, G. S., Reilly, R. R. and Akgun, A. E. (2000). Knowledge management in new product teams: Practices and outcomes. IEEE Transactions on Engineering Management, 47: 221-231.

McCrae, R. R. (1987). Creativity, divergent thinking and openness to experience. Journal of Personality and Social Psychology, 52: 1258-1265.

McCrae, R. R. (1996). Social consequences of experiential openness. Psychological Bulletin, 120: $323-337$.

McCrae, R. R. and Costa, P. T. (1996). Toward a new generation of personality theories: Theoretical contexts for the five-factor model. The Five-factor Model of Personality, ed. J. S. Wiggins, Guilford Press, New York, pp. 81-91.

McCrae, R. R. and Costa, P. T. Jr. (1989). A five-factor theory of personality. Handbook of Personality Theory and Research, eds. L. A. Pervin and O. P. John, Guilford Press, New York.

Meyer, M. H. and Utterback, J. M. (1995). Product development cycle time and commercial success. IEEE Transactions on Engineering Management, 42: 297-304.

Moriarty, R. T. and Kosnik, T. J. (1990). High-tech concept, continuity, and change. IEEE Engineering Management Review, 3: 25-35.

Morgan, B. B., Jr. and Lassiter, D. L. (1992). Team composition and staffing. Teams: Their Training and Performance, eds. R. W. Swezey and E. Salas, Ablex Publishing, Norwood, NJ, pp. $76-100$.

Mount, M. K, Barrick, M. R. and Strauss, J. P. (1994). Validity of observer ratings of the Big Five personality factors. Journal of Applied Psychology, 79, 2: 272-280. 
Neuman, G. A. and Wright, J. (1999). Team effectiveness: Beyond skills and cognitive ability. Journal of Applied Psychology, 84: 376-389.

O'Connor, G. C. and Veryzer, R. W. (2001). The nature of market visioning for technologybased radical innovation. Journal of Product Innovation Management, 18: 231-246.

Oser, R. L., McCallum, G. A., Salas, E. and Morgan, B. B., Jr. (1989). Toward a definition of team work: An analysis of critical team behavior (NTSC Tech. Rep. No. 89-018). Naval Training Systems Center, Orlando, FL.

Peeters, M. A., Van Tuijl, H. F., Rutte, C. G. and Reymen, I. M. (2006). Personality and team performance: A meta-analysis. European Journal of Personality, 20, 5: 377-396.

Podsakoff, P. M. and Organ, D. (1986). Self-reporting in organizational research: Problems and prospects. Journal of Management, 12: 531-544.

Porter, M. E. (1985). Competitive Advantage: Creating and Sustaining Superior Performance. Free Press, New York, NY.

Reilly, R. R., Lynn, G. S. and Aronson, Z. H. (2002). The role of personality in new product development team performance. Journal of Engineering and Technology Management, 19: $39-58$.

Rosenbloom, R. S. and Cusumano, M. A. (1987). Technical pioneering and competitive advantage: The birth of the VCR industry. California Management Review, 29, 4: 51-76.

Salgado, J. F. (1997). The five factor model of personality and job performance in the European community. Journal of Applied Psychology, 82: 30-43.

Salgado, J. (2002). The Big Five personality dimensions and counterproductive behaviors. International Journal of Selection and Assessment, 10, 1-2: 117-125.

Schneider, F. W. and Delaney, J. G. (1972). Effect of individual achievement motivation on group problem solving efficiency. Journal of Social Psychology, 86: 291-298.

Schutz, W. D. (1955). What makes groups productive? Human Relations, 8: 429-465.

Shaw, M. E. and Harkey, B. (1976). Some effects of congruency of member characteristics and group structure upon group behavior. Journal of Personality and Social Psychology, 34: $412-418$.

Shenhar, A. J., Dvir, D., Guth, W., Lechler, T., Panatakul, P., Poli, M. et al., (2005). Project strategy: The missing link. Paper presented at the Academy of Management Annual Conference, Hawaii.

Smith, P. G. and Reinertsen, D. G. (1997). Developing Products in Half the Time: New Rules, New Tools (2nd edn.). John Wiley and Sons, New York.

Stalk, G. J. and Hout, T. M. (1990). Competing Against Time: How Time-based Competition is Reshaping Global Markets. The Free Press, New York.

Stevens, G., Burley, J. and Divine, R. (1999). Creativity + business discipline = higher profits faster from new product development. Journal of Product Innovation Management, 16, 5: $455-468$.

Strang, D. K. (2011). Leadership substitutes and personality impact on time and quality in virtual new product development projects. Project Management Journal, 42, 1: 73-90.

Strube, M. J., Keller, N. R., Oxenburg, J. and Lapido, D. (1989). Actual and perceived group performance as a function of group composition: The moderating role of type A and B behavior patterns. Journal of Applied Social Psychology, 19: 140-158.

Tett, R. P., Jackson, D. N. and Rothstein, M. (1991). Personality measures as predictors of performance: A meta-analytic review. Personnel Psychology, 44: 703-742.

Tett, R. P., Jackson, D. N., Rothstein, M. and Reddon, J. R. (1994). Meta-analysis of personality and job performance relations: A reply to Ones, Mount, Barrick, and Hunter. Personnel Psychology, 47: 157-171.

Tellis, G. J. and Golder, P. N. (2001). Will and Vision: How Latecomers Grow to Dominate Markets. McGraw-Hill, New York.

Thoms, P., Moore, K. S. and Scott, K. S. (1996). The relationship between self efficacy for participating in self-managed work groups and the big five personality dimensions. Journal of Organizational Behavior, 17: 349-362. 
Tuckman, B. W. (1967). Group composition and group performance of structured and unstructured tasks. Journal of Experimental Social Psychology, 3: 25-49.

Tushman, M. P. and Anderson, P. (1986). Technological discontinuities and organizational environments. Administrative Science Quarterly, 31: 439-465.

Veryzer, R. W. J. (1998). Key factors affecting customer evaluation of discontinuous new products. Journal of Product Innovation Management, 15: 136-150.

Watson, D. and Tellegen, A. (1985). Toward a consensual structure of mood. Psychological Bulletin, 98: 219-235.

Wiggins, J. S. (1996). The Five Factor Model of Personality. Guilford Press, New York.

Wheelwright, S. C. and Clark, K. B. (1992). Revolutionizing Product Development: Quantum Leaps in Speed, Efficiency Quality. Free Press, New York.

Whetten, D. A. and Cameron, K. S. (2016). Developing Management Skills (9th edn.). Pearson, Upper Saddle River, NJ.

Zander, A. and Forward, J. (1968). Position in group, achievement orientation, and group aspirations. Personality and Social Psychology, 8: 282-288.

Zirger, B. J. and Hartley, J. L. (1994). A conceptual model of product development cycle time. Journal of Engineering and Technology Management, 11: 229-251.

\section{Appendix A. Five-Item Measure of the Big-Five Personal Style Traits}

(1) Conscientiousness: The extent to which NPD staff members are careful, thorough, responsible, organized, self-disciplined, scrupulous (Conscientious) versus irresponsible, disorganized, undisciplined, unscrupulous (Unconscientious).

Please place an " $\mathrm{X}$ " in the cells that best capture the distribution of your NPD staff members on conscientious:

\begin{tabular}{lccccc}
\hline & \multicolumn{4}{c}{$\begin{array}{c}\text { Neither } \\
\text { conscientious } \\
\text { nor }\end{array}$} \\
Description & $\begin{array}{c}\text { Highly } \\
\text { conscientious }\end{array}$ & $\begin{array}{c}\text { Somewhat } \\
\text { conscientious }\end{array}$ & $\begin{array}{c}\text { Somewhat } \\
\text { unconscientious }\end{array}$ & $\begin{array}{c}\text { Highly } \\
\text { unconscientious }\end{array}$ & unconscientious \\
\hline $\begin{array}{c}\% \text { Must } \\
\text { Total } \\
100 \%\end{array}$ & $-{\text {--- }{ }^{(1)}}^{(1)}$ & $-\%^{(2)}$ & $---\%^{(3)}$ & $-\%^{(4)}$ & $-\%^{(5)}$ \\
\hline
\end{tabular}

(2) Agreeableness: The extent to which NPD staff members are good-natured, gentle, cooperative, forgiving, hopeful (Agreeable) versus irritable, ruthless, suspicious, uncooperative, inflexible (Disagreeable).

Please place an " $\mathrm{X}$ " in the cells that best capture the distribution of your NPD staff members on agreeableness:

\begin{tabular}{lccccc}
\hline Description & Highly agreeable & $\begin{array}{c}\text { Somewhat } \\
\text { agreeable }\end{array}$ & $\begin{array}{c}\text { Neither } \\
\text { agreeable nor } \\
\text { disagreeable }\end{array}$ & $\begin{array}{c}\text { Somewhat } \\
\text { disagreeable }\end{array}$ & $\begin{array}{c}\text { Highly } \\
\text { disagreeable }\end{array}$ \\
\hline $\begin{array}{c}\text { \% Must } \\
\text { Total }\end{array}$ & $--\%^{(1)}$ & $--\%^{(2)}$ & $---\%^{(3)}$ & $--\%^{(4)}$ & $-\%^{(5)}$ \\
$100 \%$ & & & & & \\
\hline
\end{tabular}


(3) Extroversion-Introversion: the extent to which NPD staff members are sociable, talkative, assertive, active (Extroverted) versus retiring, sober, reserved, cautious (Introverted).

Please place an " $\mathrm{X}$ " in the cells that best capture the distribution of your NPD staff members on extraversion:

\begin{tabular}{lccccc}
\hline Description & $\begin{array}{c}\text { Highly } \\
\text { extroverted }\end{array}$ & $\begin{array}{c}\text { Somewhat } \\
\text { extroverted }\end{array}$ & $\begin{array}{c}\text { Neither } \\
\text { extroverted } \\
\text { nor introverted }\end{array}$ & $\begin{array}{c}\text { Somewhat } \\
\text { introverted }\end{array}$ & Highly introverted \\
\hline $\begin{array}{c}\text { \% Must } \\
\text { Total }\end{array}$ & $-\%^{(1)}$ & $-\%^{(2)}$ & $--\%^{(3)}$ & $-\%^{(4)}$ & $-\%^{(5)}$ \\
$100 \%$ & & & & \\
\hline
\end{tabular}

(4) Openness: The extent to which team members are imaginative, sensitive, intellectual, polished (Open) versus down to earth, insensitive, narrow, crude, simple (Unopen).

Please place an " $\mathrm{X}$ " in the cells that best capture the distribution of your NPD staff members on openness:

\begin{tabular}{lccccc}
\hline Description & Highly open & Somewhat open & $\begin{array}{c}\text { Neither open } \\
\text { nor unopen }\end{array}$ & $\begin{array}{c}\text { Somewhat } \\
\text { unopen }\end{array}$ & Highly unopen \\
\hline $\begin{array}{c}\text { \% Must } \\
\text { Total 100\% }\end{array}$ & $-\%^{(1)}$ & $-\%^{(2)}$ & $-\%^{(3)}$ & $-\%^{(4)}$ & $\%^{(5)}$ \\
\hline
\end{tabular}

(5) Emotional stability: The extent to which team members are calm, enthusiastic, poised, secure (Stable) versus depressed, angry, emotional, insecure (Unstable).

Please place an " $\mathrm{X}$ " in the cells that best capture the distribution of your NPD staff members on emotional stability:

\begin{tabular}{lccccc}
\hline Description & Highly stable & $\begin{array}{c}\text { Somewhat } \\
\text { stable }\end{array}$ & $\begin{array}{c}\text { Neither stable } \\
\text { nor unstable }\end{array}$ & $\begin{array}{c}\text { Somewhat } \\
\text { unstable }\end{array}$ & Highly unstable \\
\hline $\begin{array}{c}\text { \% Must } \\
\text { Total } 100 \%\end{array}$ & $-{\text {-- } \%^{(1)}}$ & $-\%^{(2)}$ & $---\%^{(3)}$ & $-\%^{(4)}$ & ${ }_{---\%^{(5)}}$ \\
\hline
\end{tabular}

\section{Biography}

Zvi H. Aronson is affiliate Associate Professor at the School of Business, Stevens Institute of Technology, USA. Dr. Aronson's interests center on the behavioral aspects of innovation and technology management. Zvi joined the Editorial Board of IEEE Transactions on Engineering Management in 2018. His research is focused on the behavioral features of project leader and team performance and on the role played by culture in project-based contexts. Implications are for identifying levers available to the project leader to alter culture and motivate workers and how they 
affect success in project-based work. Zvi's work appears in several journals including RED Management, the International Journal of Selection and Assessment, Project Management Journal, the Journal of Engineering and Technology Management, Journal of High Technology Management Research, the International Journal of Technology Management and in several book chapters. A book to which Zvi contributed a chapter, on managing contextual performance, received the R. Wayne Pace Book of the Year Award from the Academy of Human Resource Management, USA. He received the best paper award from the International Journal of Innovation and Technology Management. Dr. Aronson spearheaded the Stevens' Institute Review Board for the protection of human subject in research. Zvi is the Heath Lecture Series Lead. Prior to joining Stevens' faculty, he was employed at Bakara Ltd., Israel, where he conducted research in the areas of training and selection and provided software instruction to clients.

Richard R. Reilly is emeritus Professor at the School of Business, Stevens Institute of Technology, USA. He received his PhD from the University of Tennessee at Knoxville. Before joining Stevens, he was a Research Psychologist for Bell Laboratories, the Educational Testing Service and AT\&T. He has developed and delivered courses in project and team leadership and recently headed a team that won a grant from the Project Management Institute for the human side of project management. He has over 60 publications related to organizational behavior and team performance. Recent publications include Blockbusters: The Five Keys to Developing Great New Products, HarperCollins, 2002; How to build a blockbuster (Boston, MA, Harvard Business Review, 2002). He is a Fellow of the American Psychological Association and the American Psychological Society. He is on the Editorial Board of Personnel Psychology.

Gary S. Lynn is a Full Professor at Stevens Institute of Technology. Dr. Lynn has authored or co-authored five books and over 60 refereed publications at the intersection of technology, marketing, entrepreneurship and new product development. Dr. Lynn has 10 years of industrial experience; he started, built and sold three companies. He was formerly a technical design and marketing specialist at the General Electric Company, where he designed components of aircraft engines, held a "Secret" security clearance, and developed and implemented commercialization plans for high-technology products including robotics, numerical and programmable controls, artificial vision systems and CAD/CAM equipment. Dr. Lynn was also Director of New Product and Market Development for the Guardian Products Division of Sunrise Medical where he conducted trade negotiations with the Minister of Economics in Taiwan and the Minister of Trade in the Philippines. 